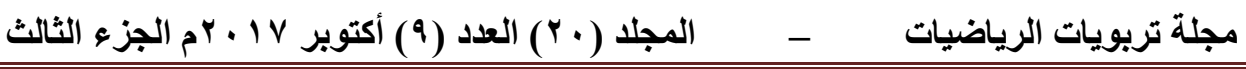

هدى همارسة هماتمات المرحلة الثانوية لمهارات هما وراء المعرفة في تدريس

الرياضيات وعلاقتها بمتغيرات المهنة

بحث مشتق من رسالة ماجستير

أبلدرية حميا رمضاض ريات بالمرحلة الثربية

إشر افت

د. عبيز سليمان حسين

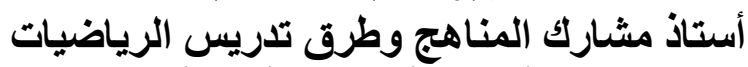

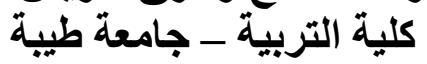

المملكة العربية السعودية 


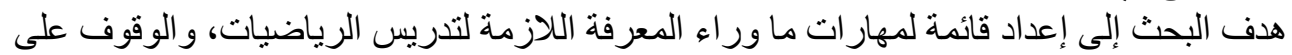

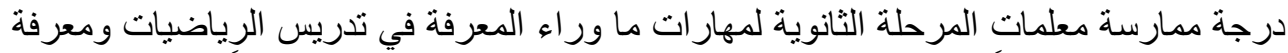

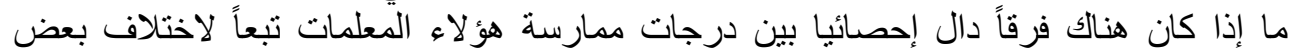

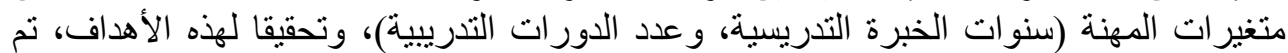

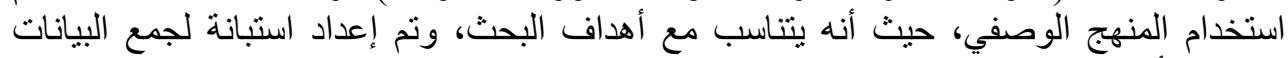

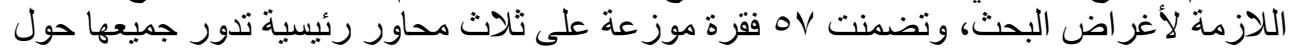

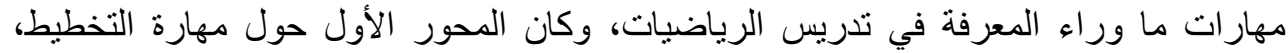

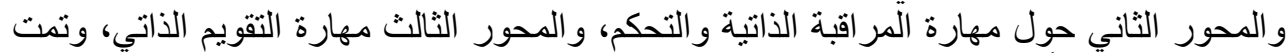

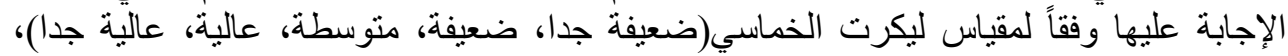

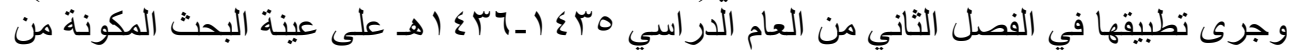

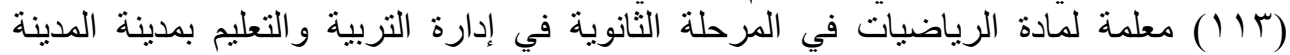

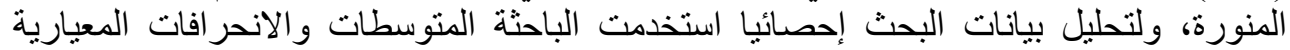

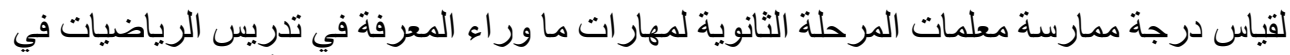

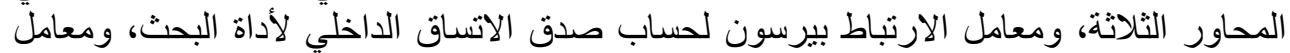

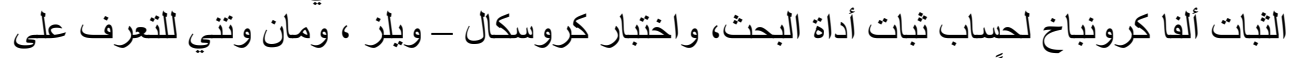

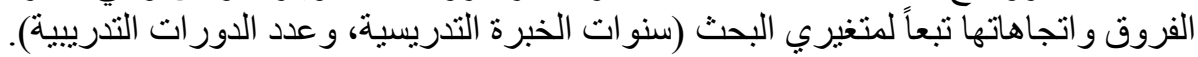
وخلص البحث إلى مجمو عة النتائج التالية: ا إعداد قائمة لمهار اتهُ ما ور اء المعرفة البهة اللازمة لعملية تدريس الرياضيات و التي تضمنتها

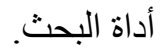
r جاءت درجة ممارسة معلمات المرحلة الثانوية لمهارات ما وراء الئه المعرفة في تدريس

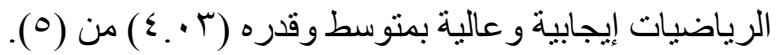

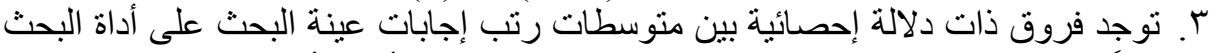

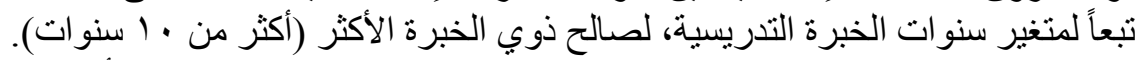

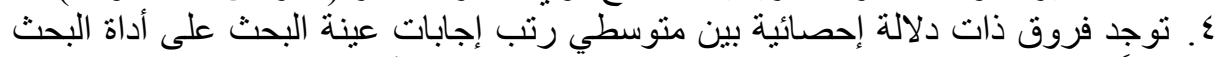

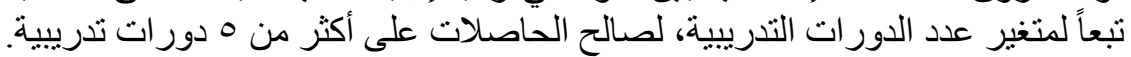

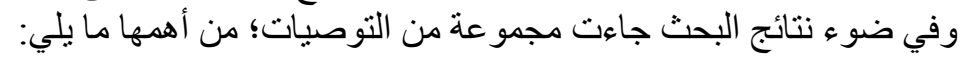

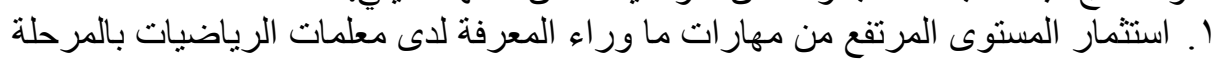

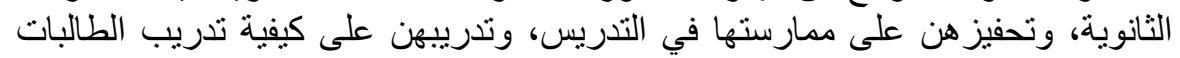

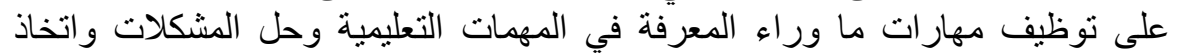

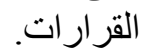

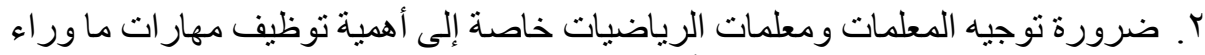

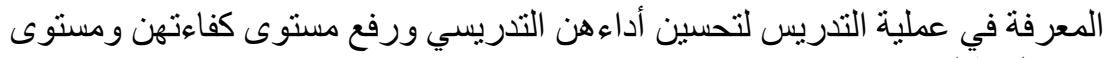
تحصيل طالباتهن. 


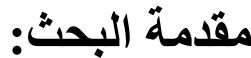

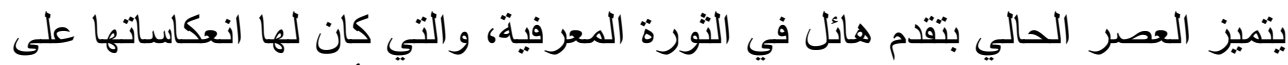

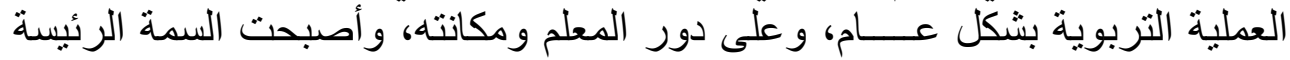

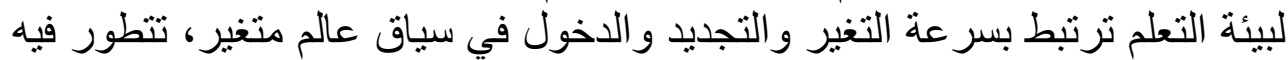

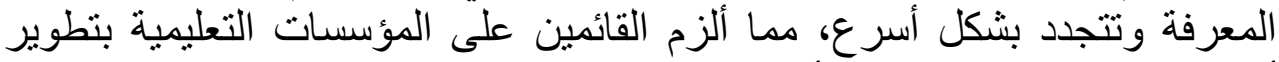
أساليبها في معالجة المعرفة، و ألا تقتصر وظيفة التعليم على نقل التعل المعلومات.

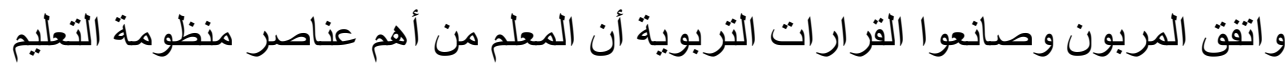

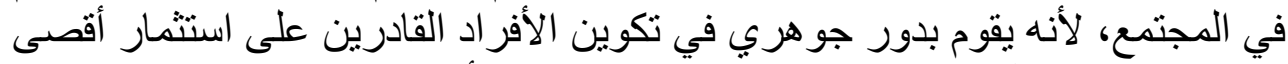

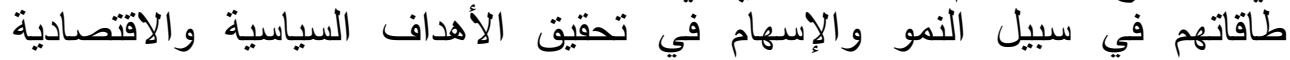

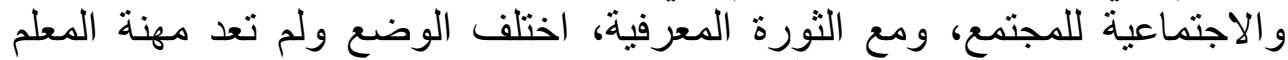

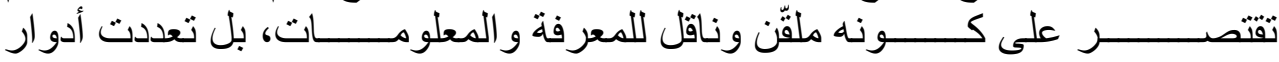

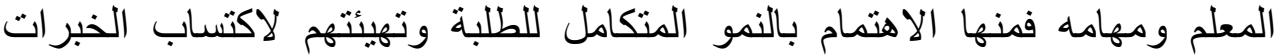

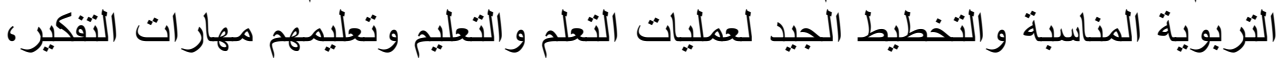

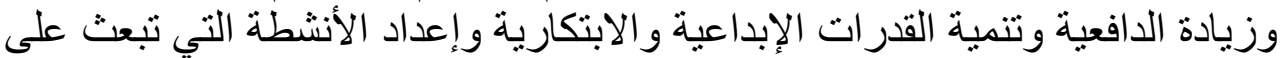

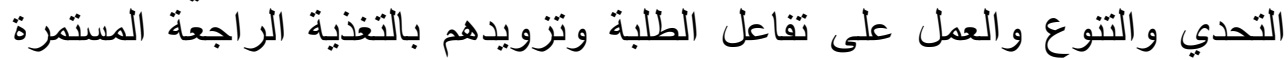

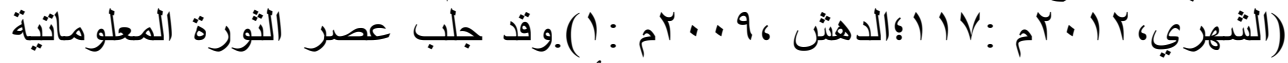

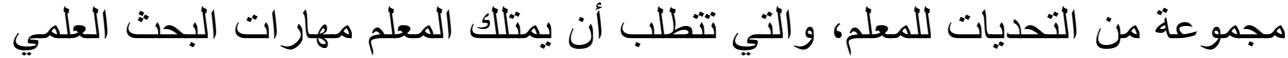

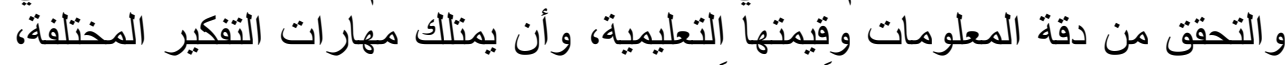

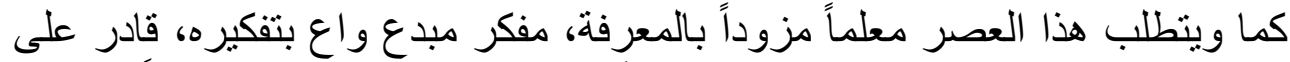

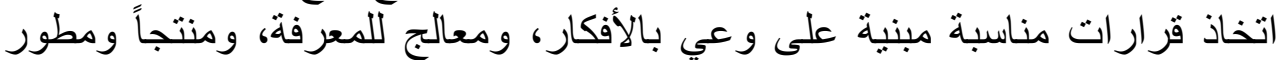

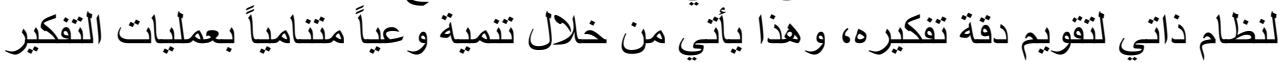

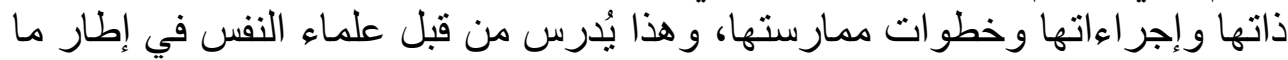

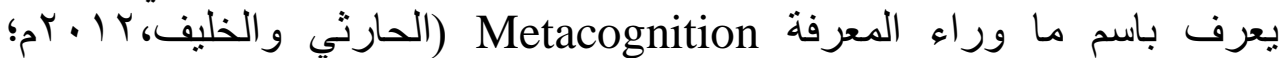

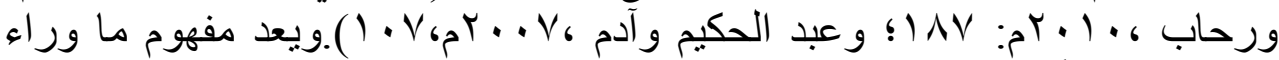

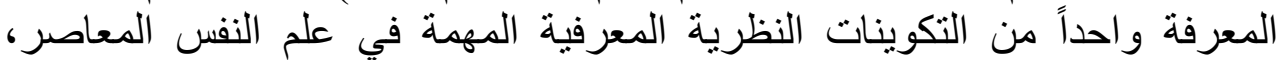

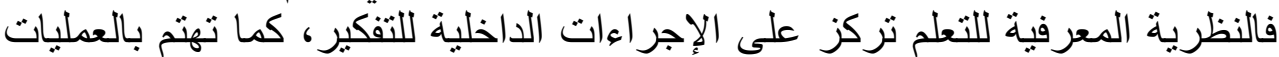

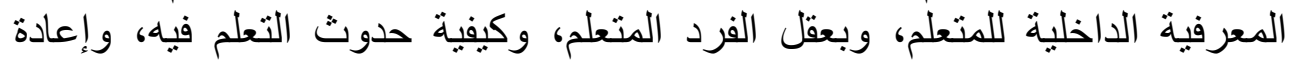

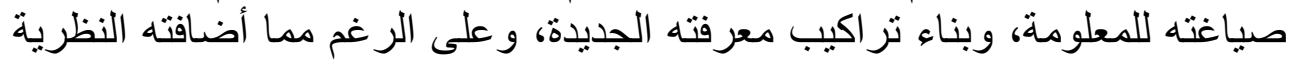

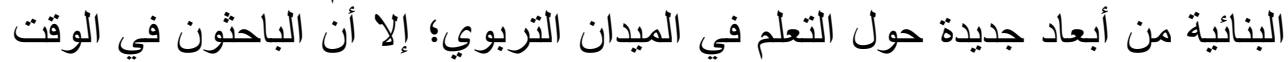

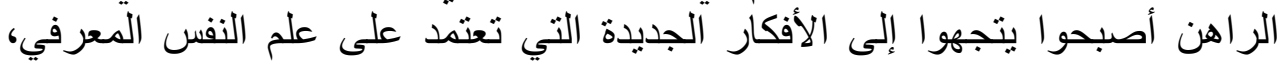

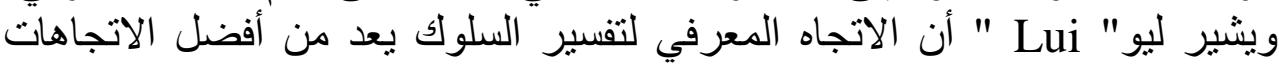


المعاصرة لفهم الكثير من جوانب النشاط العقلي المعرفي المرتبط بهذا السلوك، كما

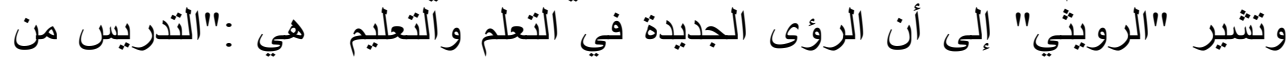

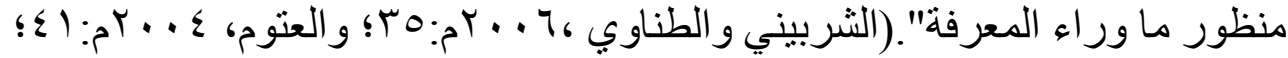

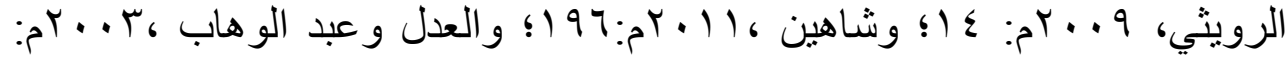

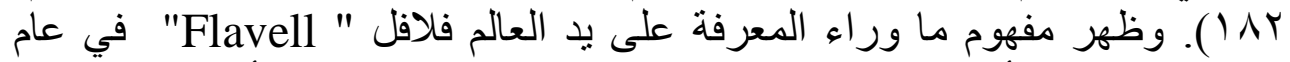

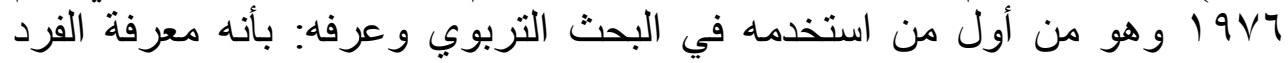

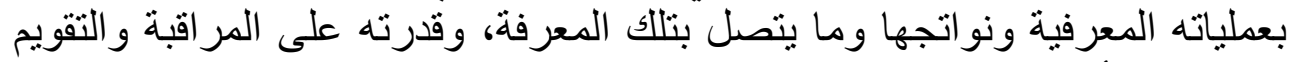

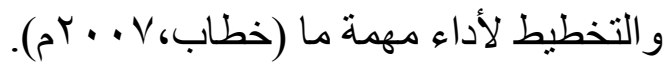

ويدل مفهوم ما ور اء المعرفة على عمليات التفكير العليا التي تتحكم في توجيه و إدارة

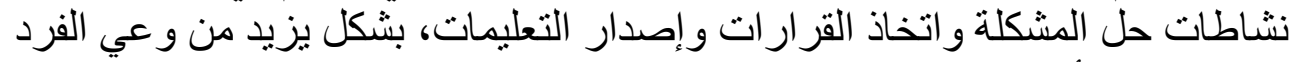

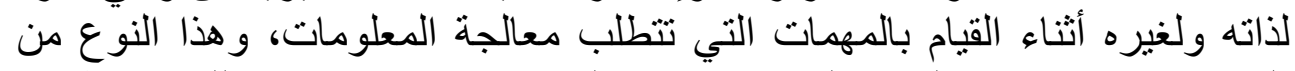

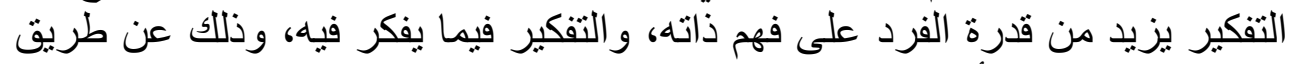

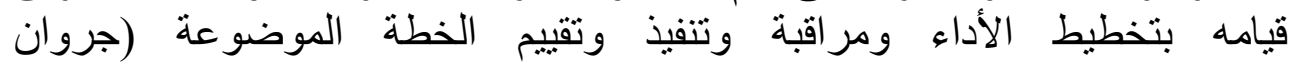
. ( $\varepsilon \Lambda_{0}{ }^{2} r+1 \cdot 6$

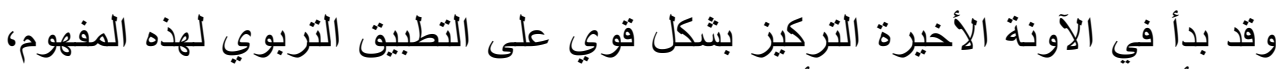

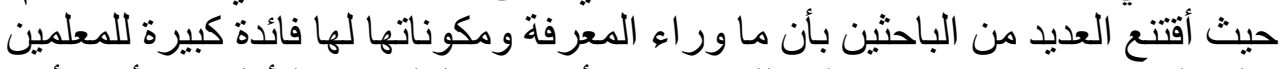

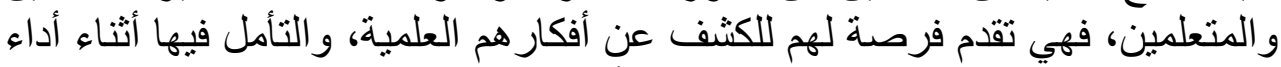

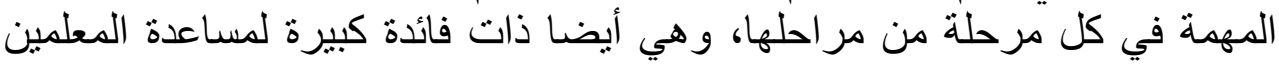

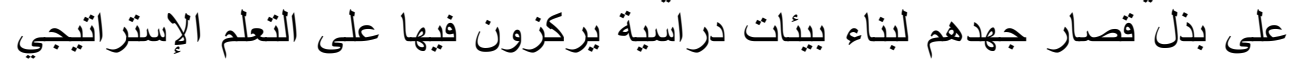

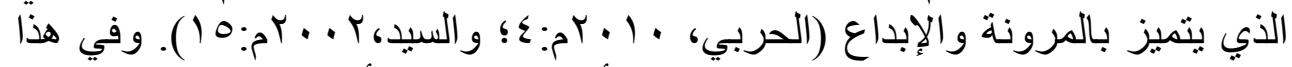

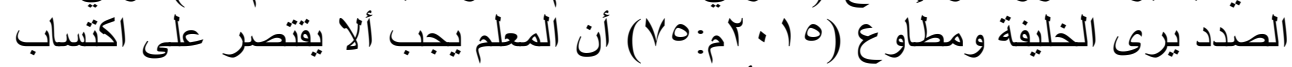

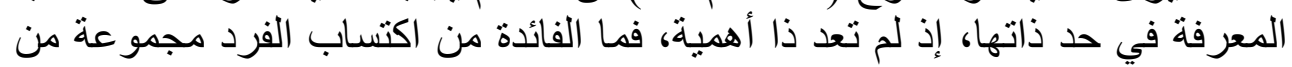

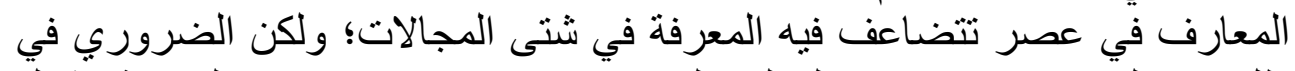

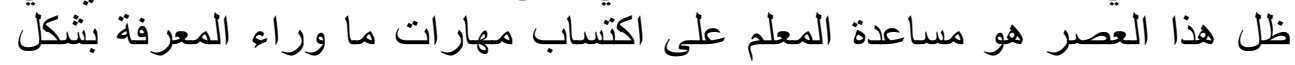

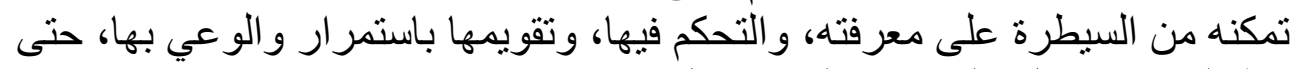
لا يُسلم بما يحصل عليه من معلومات؛ بل يقل يقو مها ويطور ها.

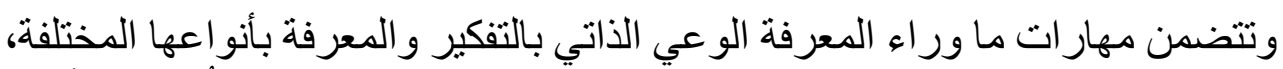

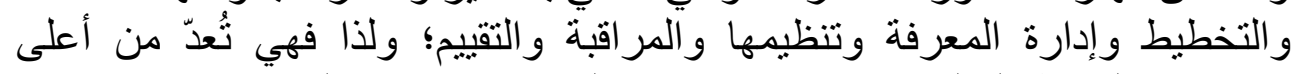

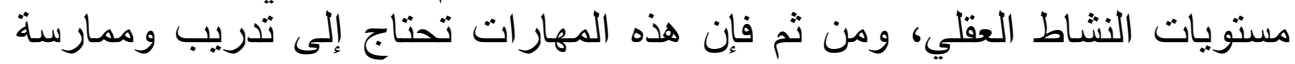

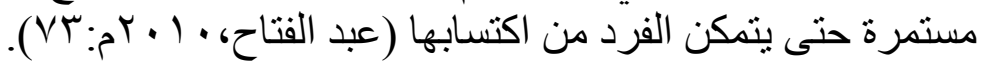


كما أشار العديد من الباحثين إلى أن المعلمون يحتاجون إلى أن يكون لديهم وعي

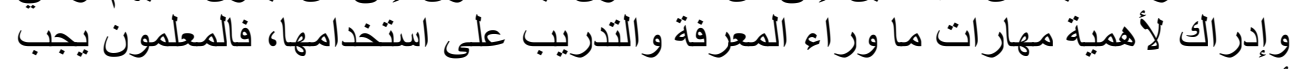

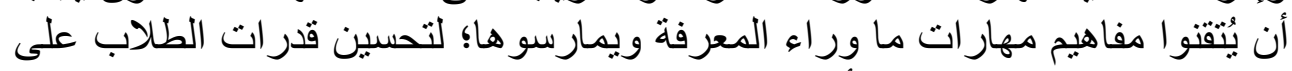

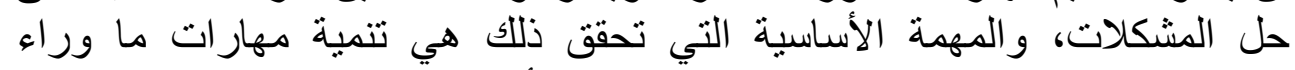

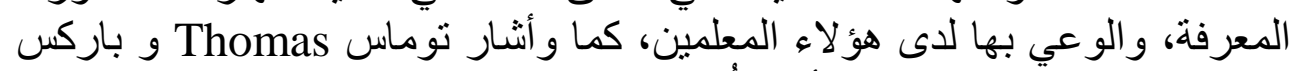

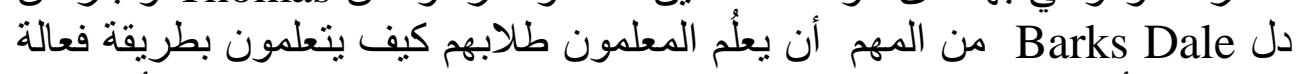

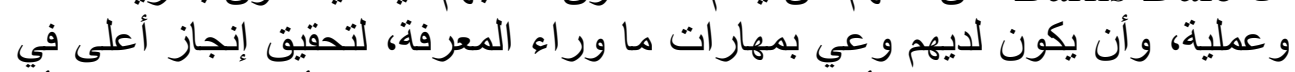

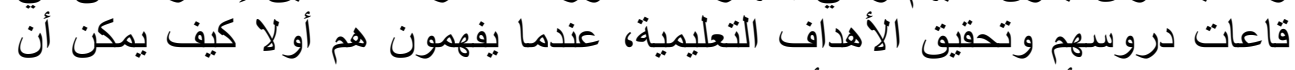

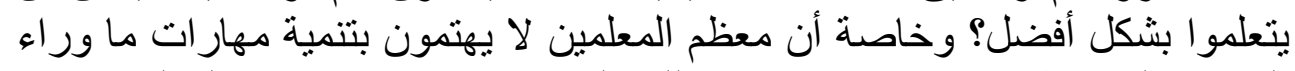

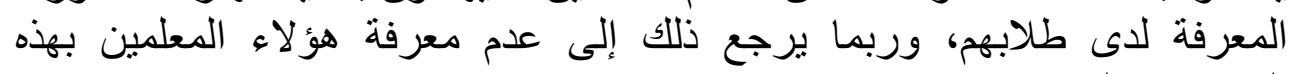

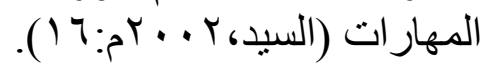

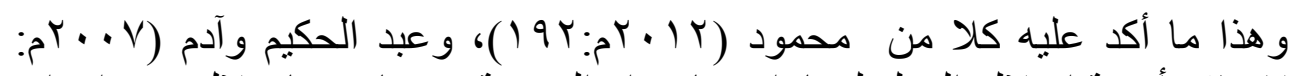

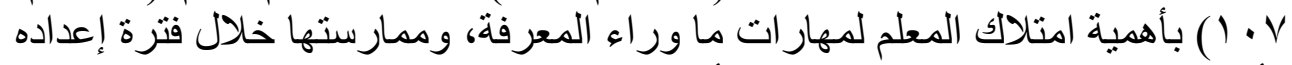

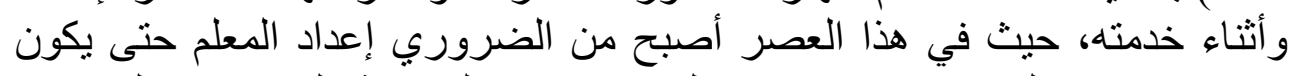

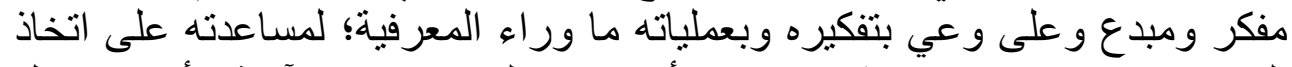

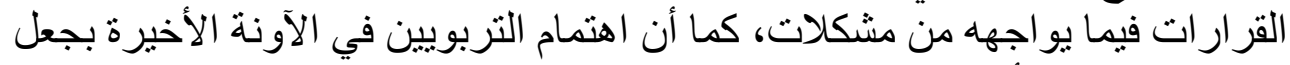

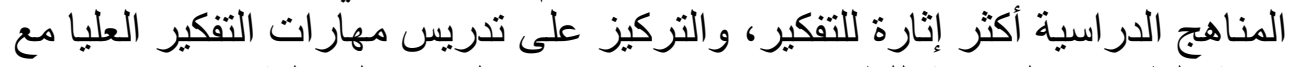

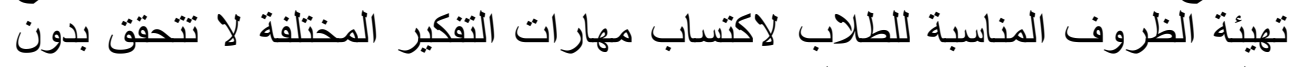
معلم واعي بمهار ات ما ور اله المعرفة.

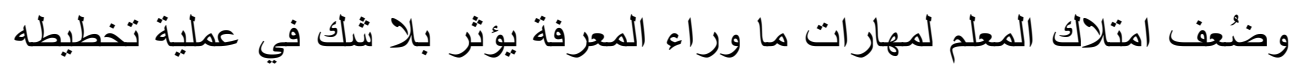

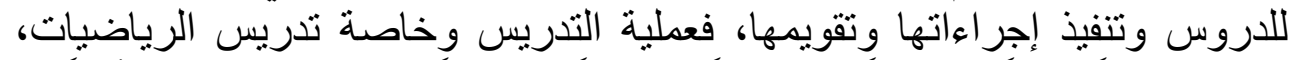

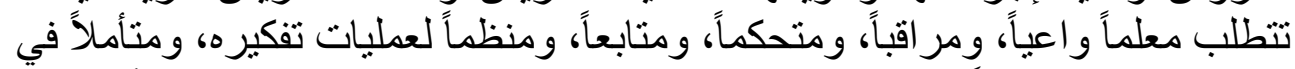

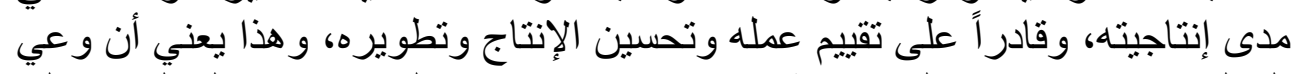

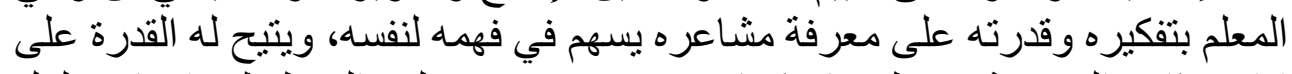

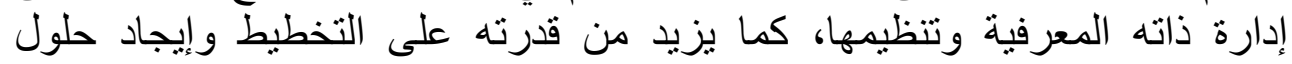

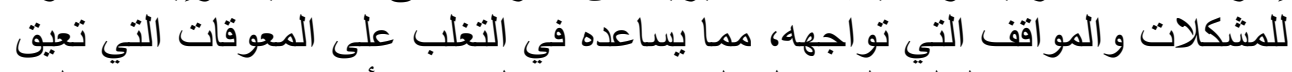

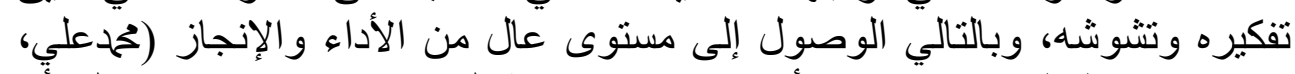

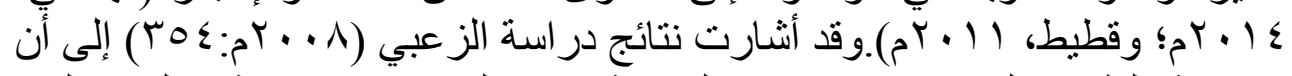

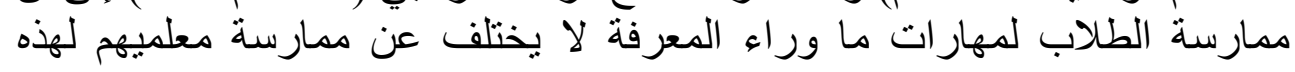

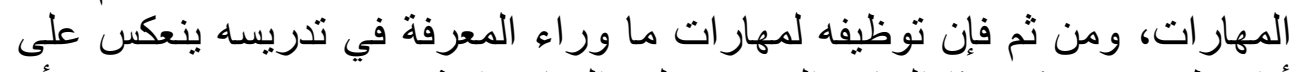

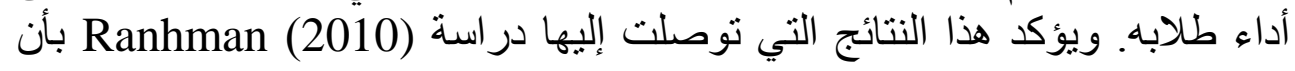


هنالك علاقة إيجابية بين وعي المعلمين بما وراء المعرفة، وو وعي طلابهر، فالمعلمين

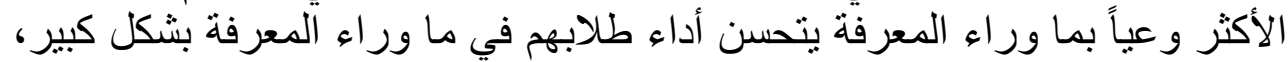

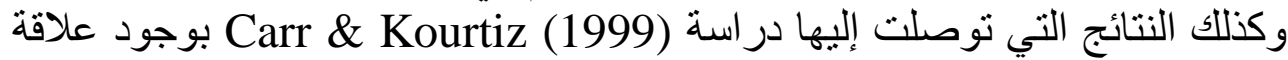
موجبة دالة إحصائيا بين إدرالك المعلمين لما وراء المعرفة ورائة والتحصيل الدراسي للطلاب.

ويعدّ منهج الرياضيات من المناهج الأساسية التي لا يمكن الاستغناء عنها في أي نظام

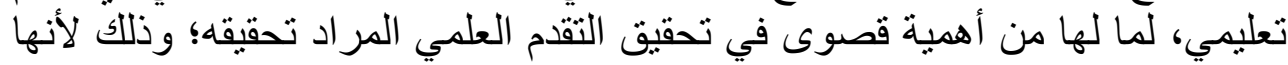

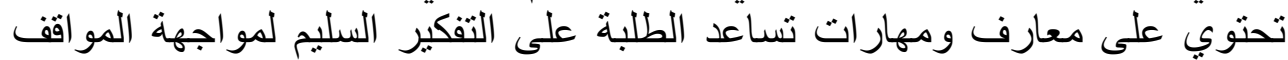

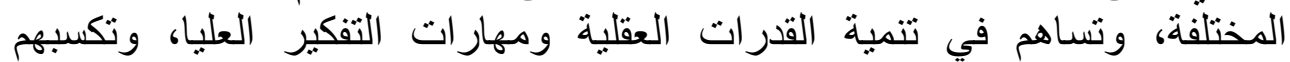

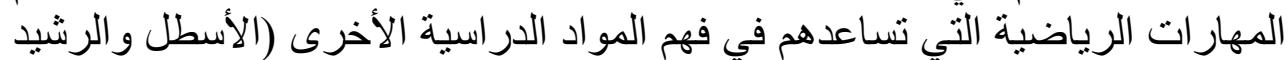

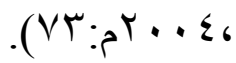

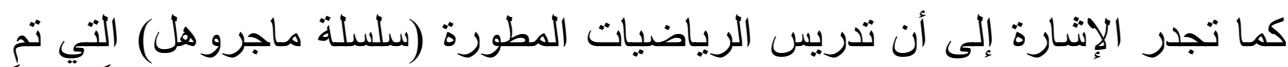

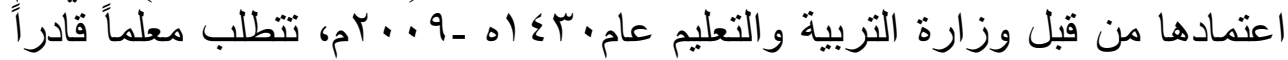

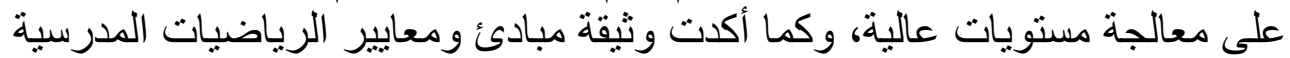

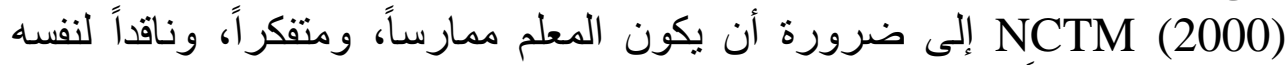

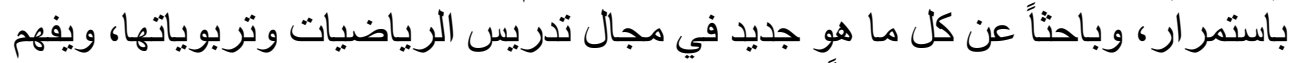

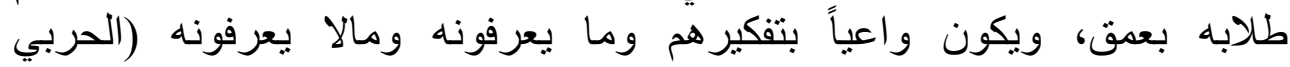

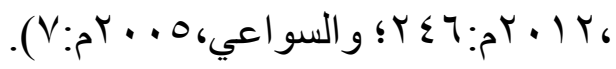

مشكلة البحث:

تبلورت مشكلة البحث لاي الباحثة مما سبق ذكره من خلال مر اجعة الدر اسات السابقة

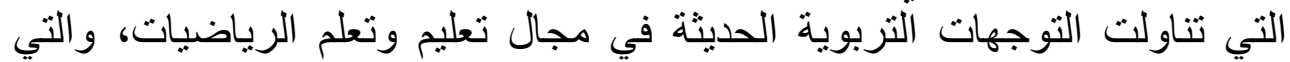

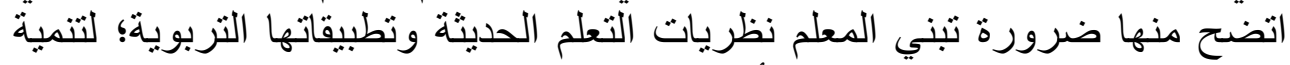

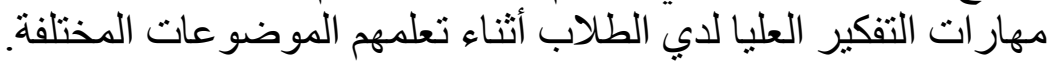

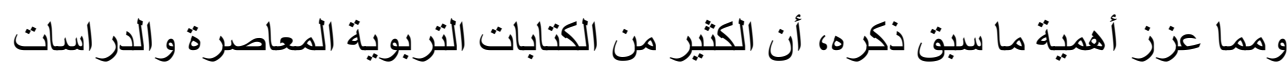

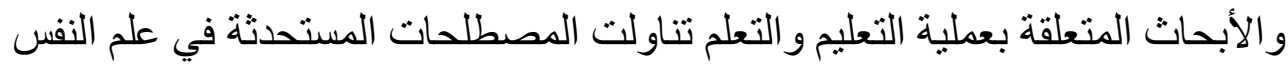

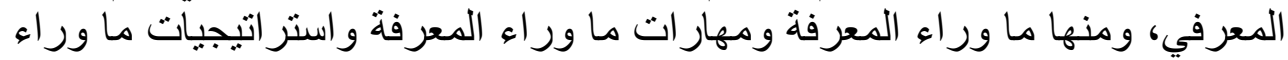

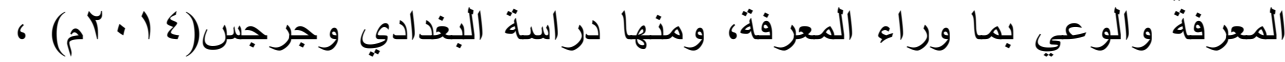

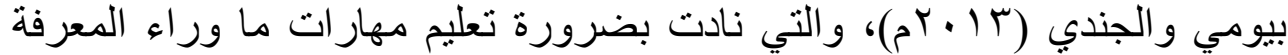

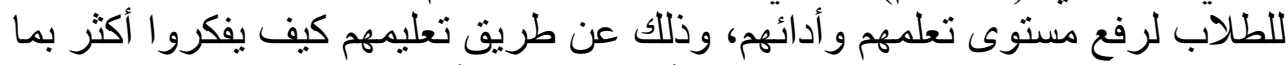

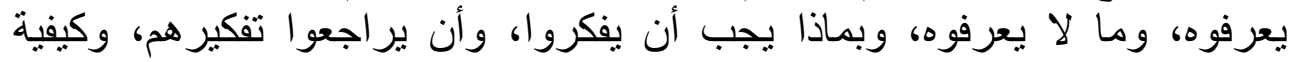




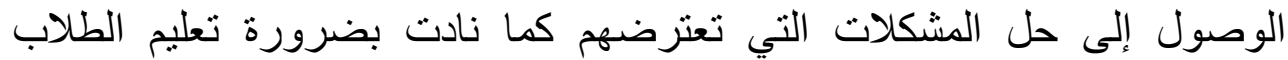

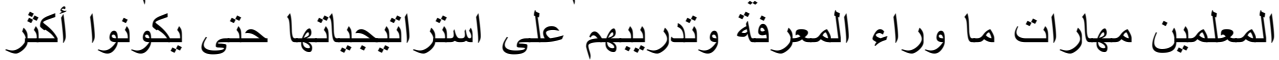

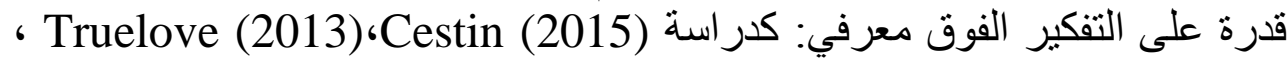

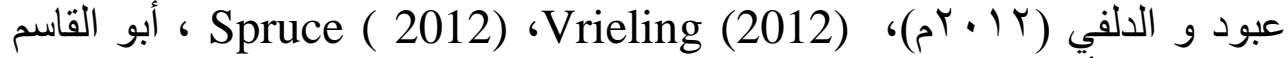

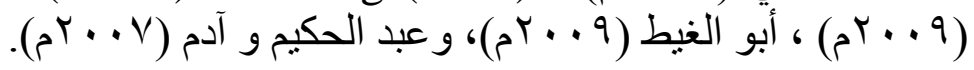

ويؤكد كلاو "kluwe" على ضرورة بحث ما ور اء المعرفة لدى الأفر اد، مما يمكننا

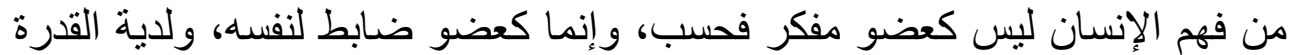

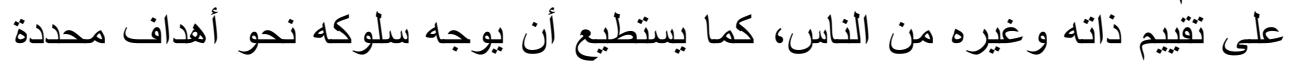

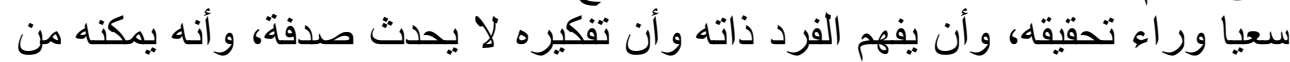

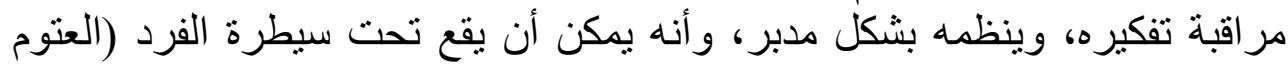

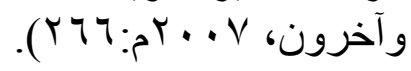

و انطلاقاً من الاهتمام المتز ايد بمهار ات ما ور اء المعرفة، قامت المات الباحثة بمحاولة إعداد

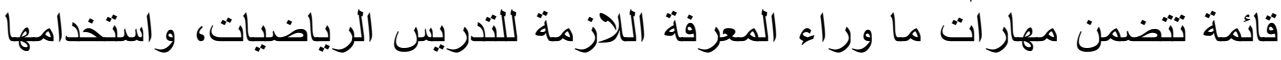

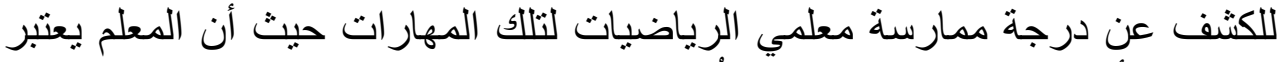

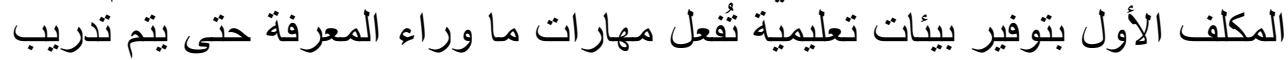

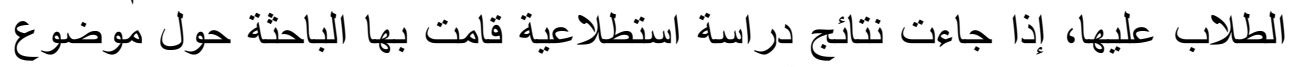

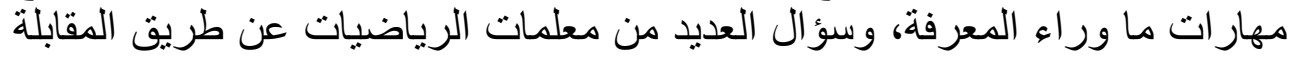

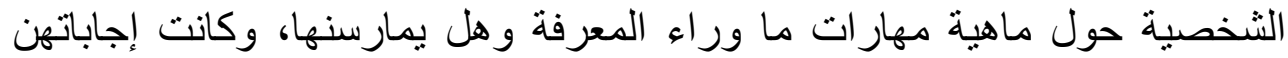

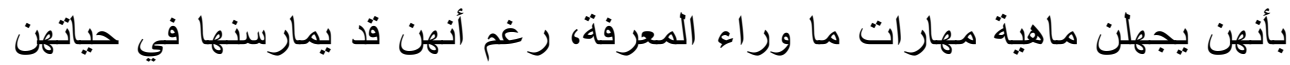
المهنية بدون الوعي بها.

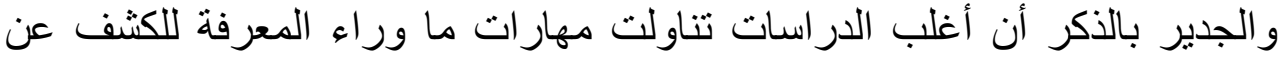

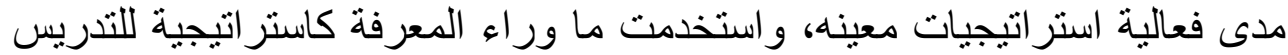

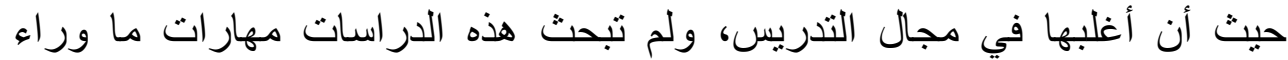

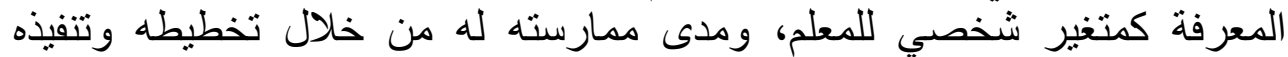

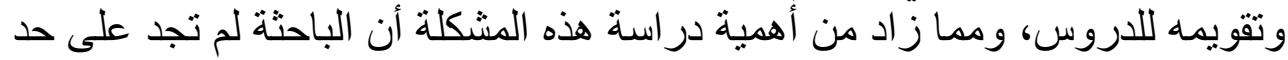
علمها در اسة تكثف عن درجة ممارسة المعلمين لمهار ات ما ما ور اء المعة المعرفة.

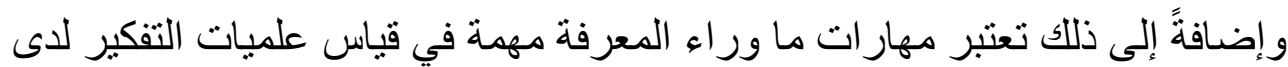

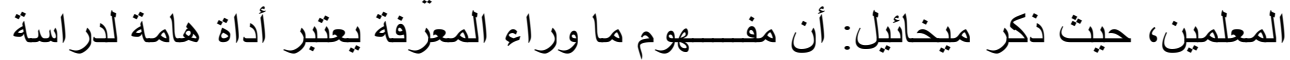

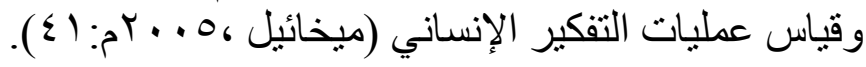


ومن جانب آخر، لعل هذا البحث يسهم في الكثف عن سبب من أسباب ضعف التف أداء

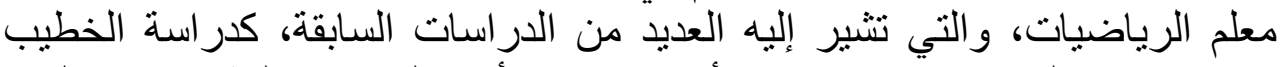

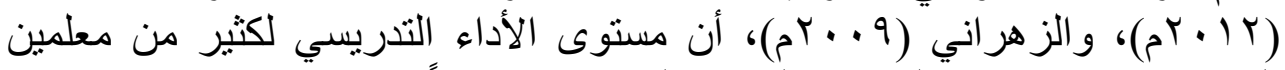

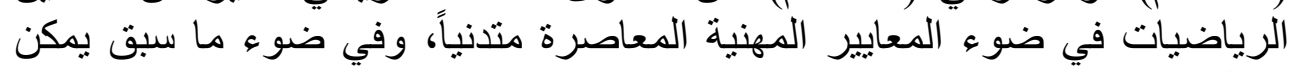

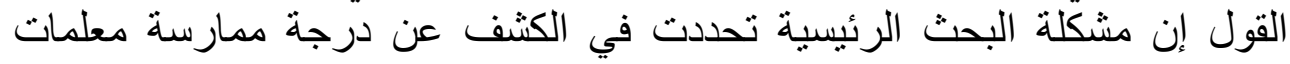

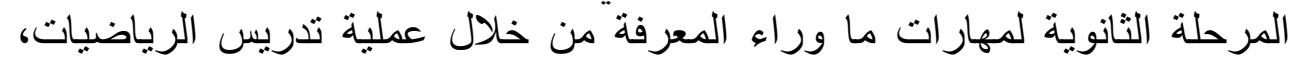

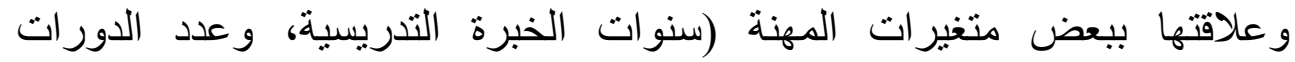
التدربيية).

السؤال الرئيس: ما مدى ممارسة معلمات المرحلة الثانوية لمهارات ما مأوراء وراء

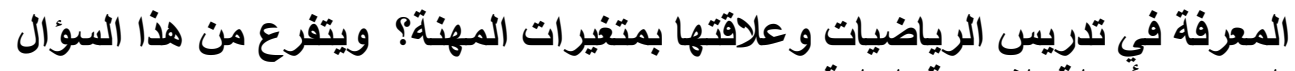

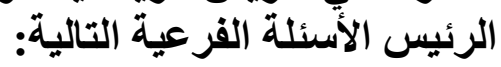

ا ـ ما مهار ات ما ور اء المعرفة اللإزة التهة لعملية تدريس الرياضيات؟

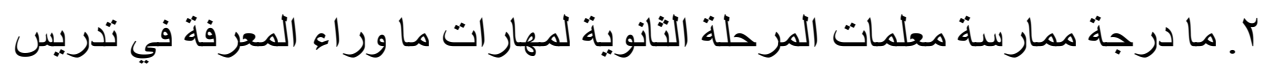
الرياضبات؟ ما درهة

\section{فرضيات البحث:}

لا يوجد فرق دال إحصائياً عند مستوى الدلالة أقل من (0. • • ) بين متوسطات

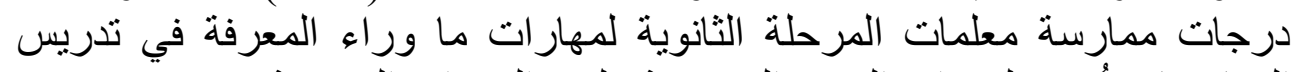

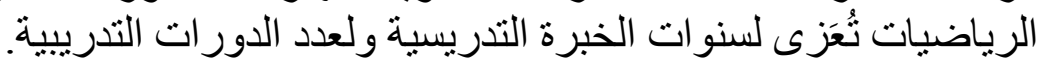

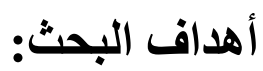

هدف البحث إلى تحقيق ما يلي:

ا. إعداد قائمة لمهار ات ما ور اء المعرفة اللازمة في تدريس الرياضيات.

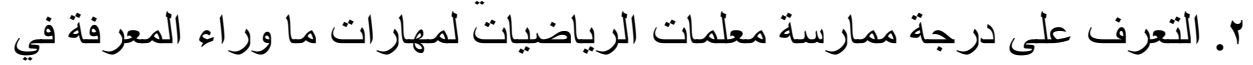
تدريس الرياضيات في المرحلة الثانوية.

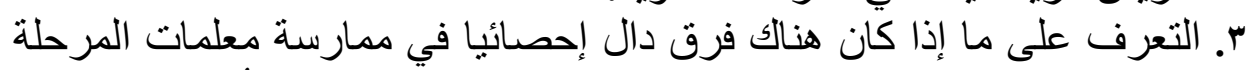

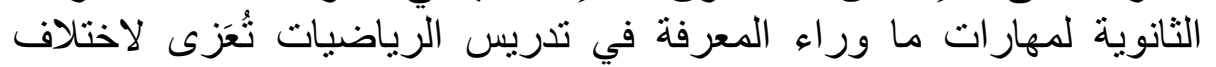

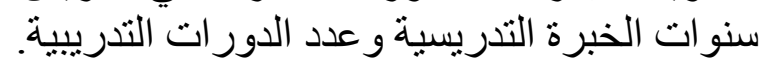




\section{أهمية البحث: \\ تكمن أهمية البحث في تحقيق ما يلي: البه}

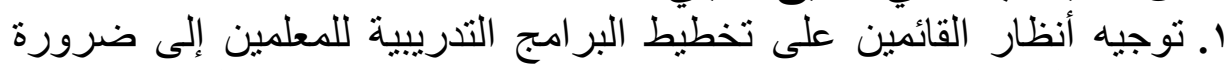

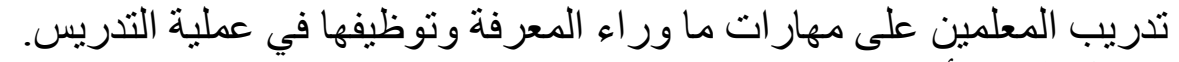

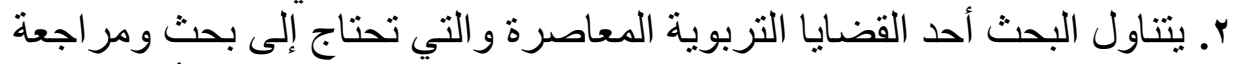

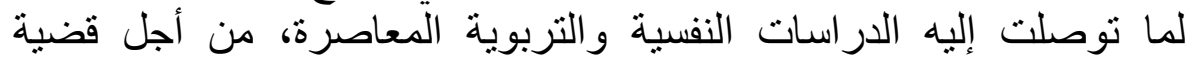

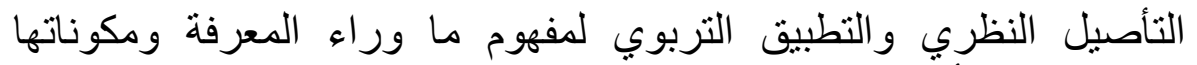

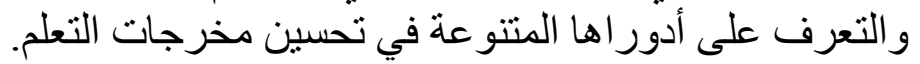

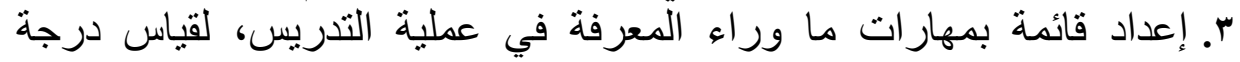

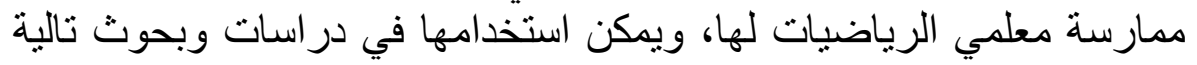

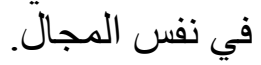
منهج البحث: في البنا: استخدمت الباحثة في هذا البحث المنهج الوصفي، باعتباره المنهج المناسب لتحقيق

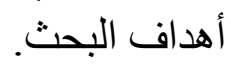

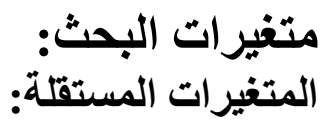

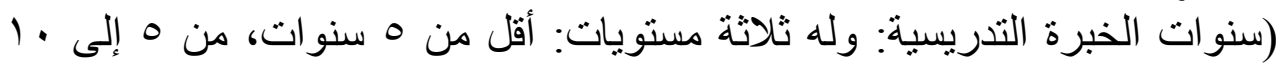

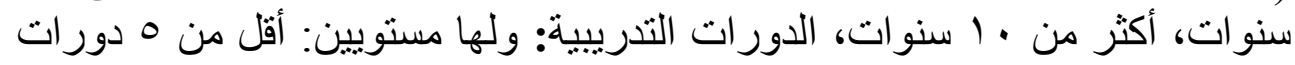

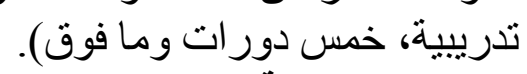
المتغيرات التابعة: درجة ممارسة أفراد عينة البحث لمهارات ما وراء المعرفة في عملية تدريس الرياضيات. مجتمع البحث: يتكون مجتمع البحث الحالي من جميع معلمات الرياضيات للمرحلة الثانوية في منطقة

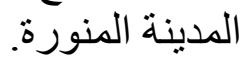
عينة البحث:

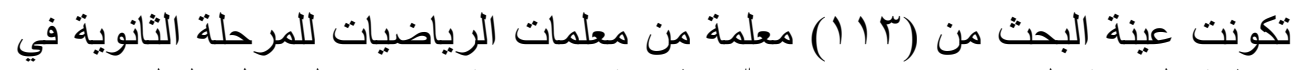

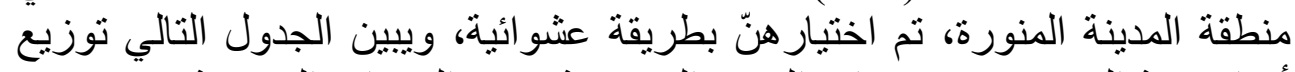
أفر اد عينة البحث حسب سنوات الخبرة التدريسية و عدد الدور ات اتلة التدريبية. 


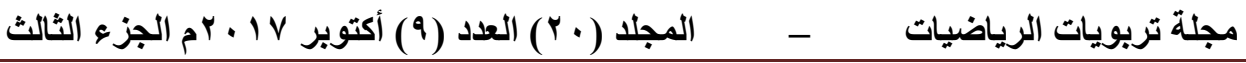

مواصفات عينة البحث:

توزيع أفراد العينة وفقا لمتغيرسنوات الخبرة التدريسية وعدد الدورات التدريبية

\begin{tabular}{|c|c|c|c|}
\hline 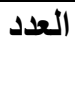 & عدد الدوريةت & العدد & سنوات الخبرة التتريسية \\
\hline 0. & اقل من • دورات & Y $\varepsilon$ & اقل من • سنوات \\
\hline 4 & • دورات فما فوق & $r V$ & من ه ـ. 1 سنوات \\
\hline \multirow[t]{2}{*}{114} & المجموع & TY & أكثر من · ـ سنوات \\
\hline & & $11 \pi$ & المجموع \\
\hline
\end{tabular}

أداة البحث:

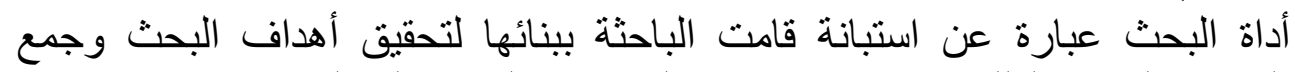

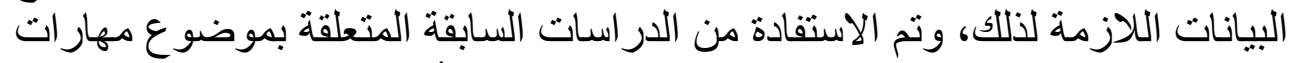

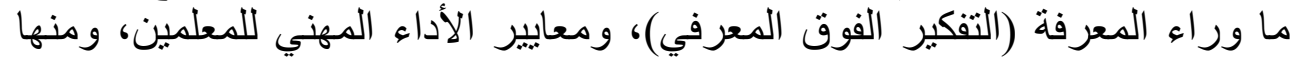

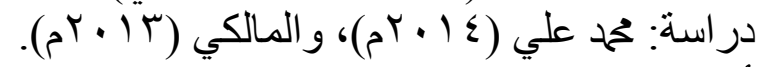

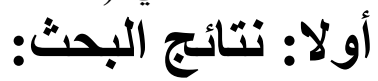

النتائج المتعلقة بالسؤال الأول: ما مهارات ما وراء المعرفة اللازمة في تدريس

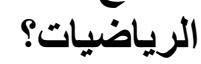

وللإجابة عن هذا السؤال قامت الباحثة باثتقاق مجموعة من الفقرات لكل مهارة

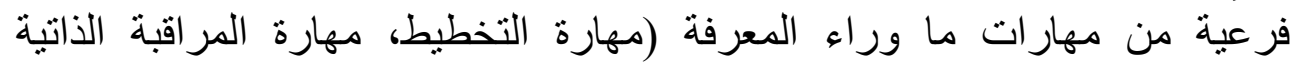
و التحكم، مهارة التقويم الذاتي)، والتي تم الاتهات مناق عليها من قبل العديد من الباحثين،

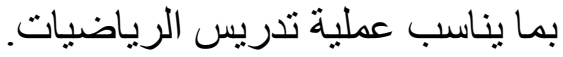

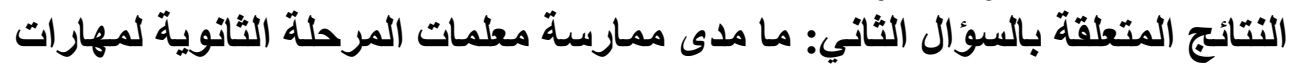

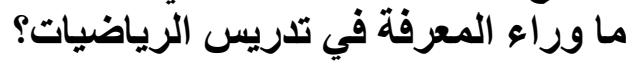

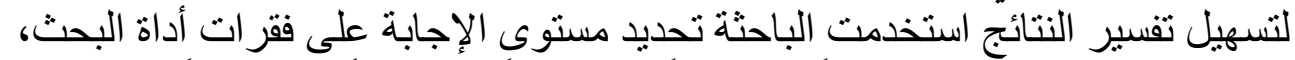

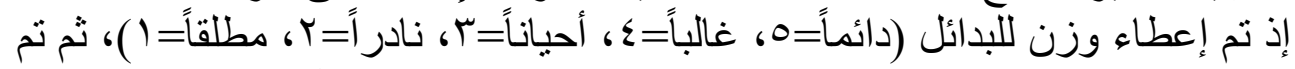

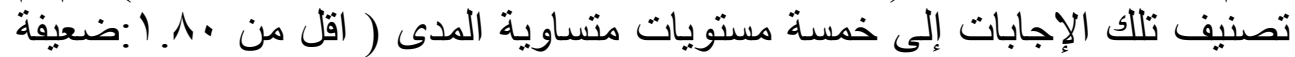

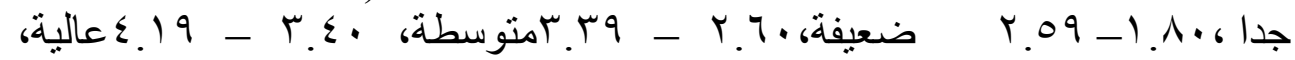

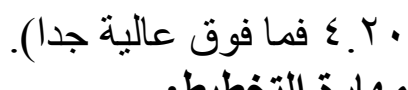
مهارة التخطيط:

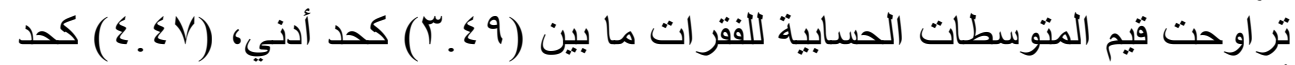

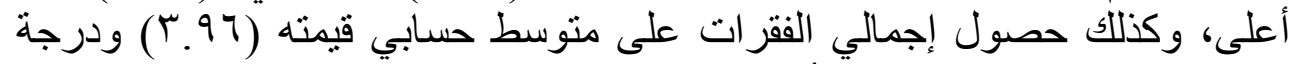

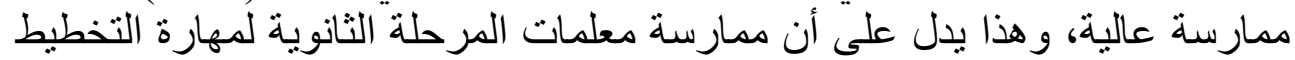
في تدريس الرياضيات كانت بدرجة ولة عالية. 


\section{مهارة المراقبة الأتية والتحكم:}

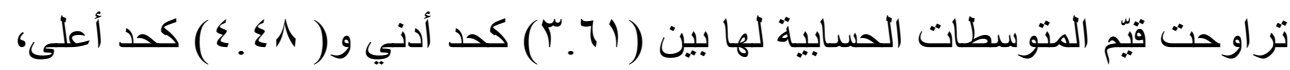

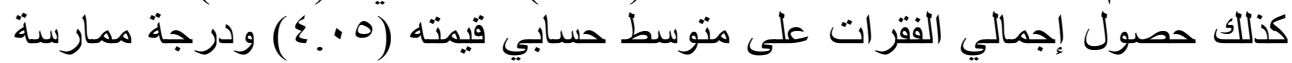

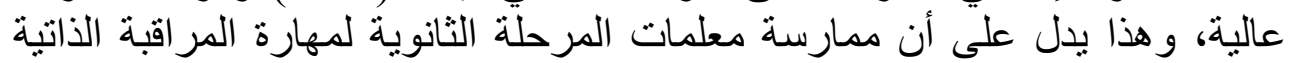

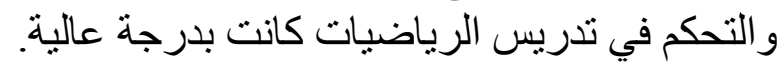

\section{مهارة التقويم الذاتي: - ماتي}

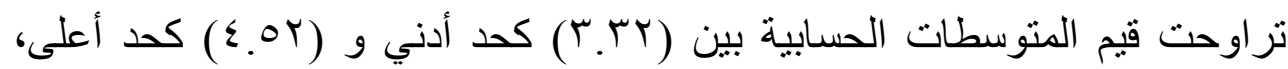

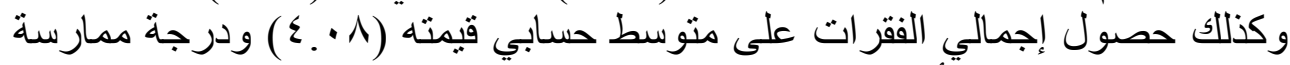

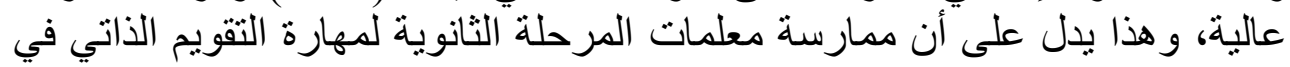
تدريس الرياضيات كانت بدرجة أنة عالية.

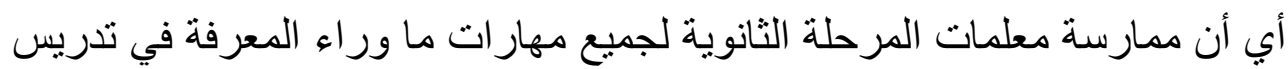

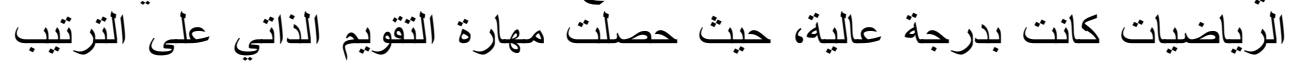

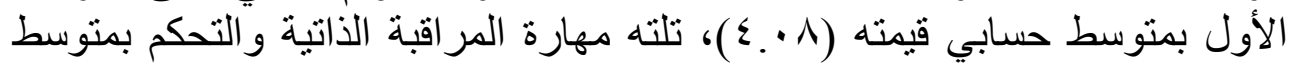

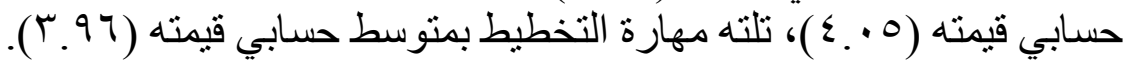

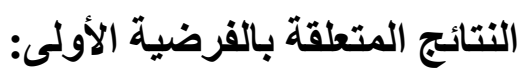

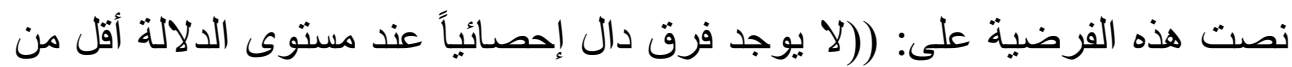

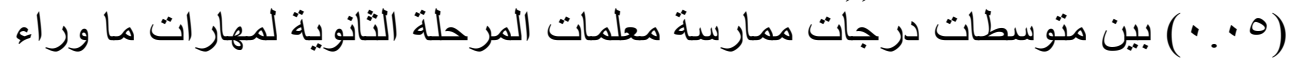
المعرفة في تدريس الرياضيات تعزى لسنو ات الخبرة التدريسية)).

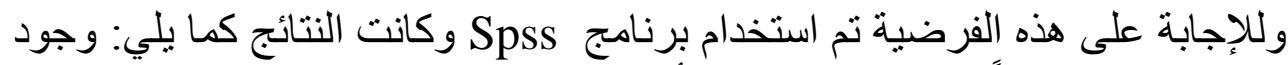

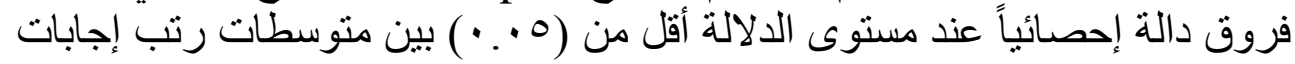

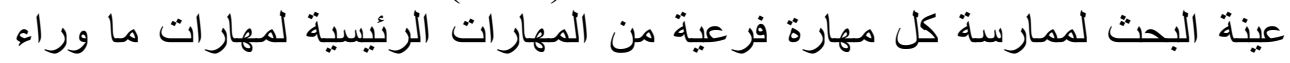

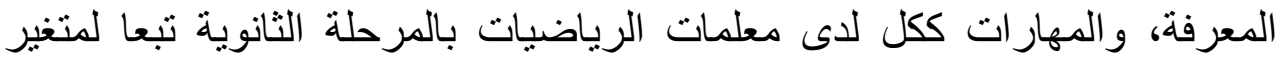
سنو ات الخبرة التدريسية، وبذلك ترفض التض الفرضية الصفرية وتقبل الفرضية البديلة. وتم الكثف عن مصدر الفروق من أب مستويات متغير سنوات الخبرة التدريسية

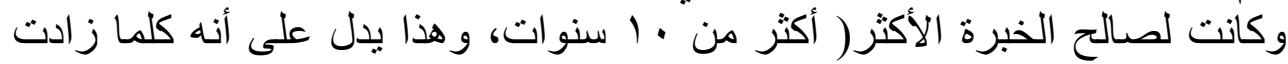

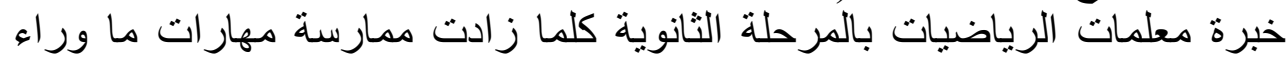

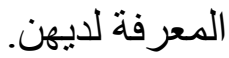




\section{النتائج المتعلقة بالفرضية الثاتية:}

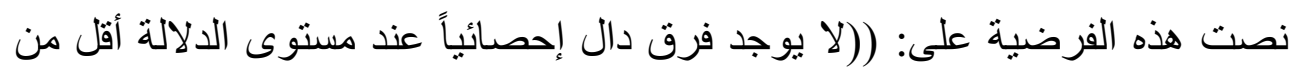

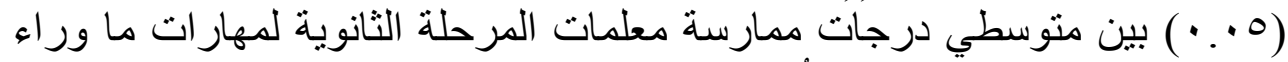

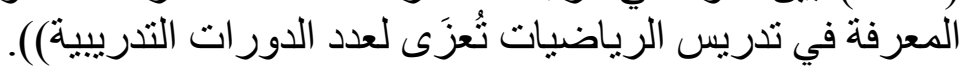

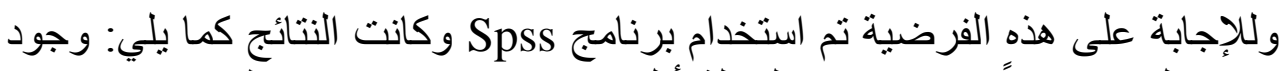

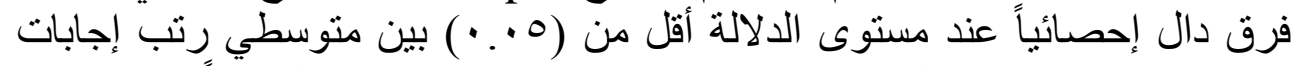

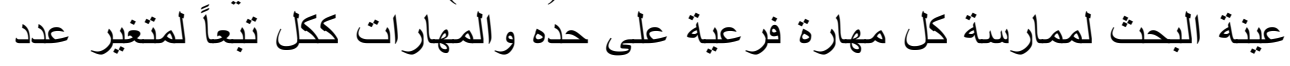

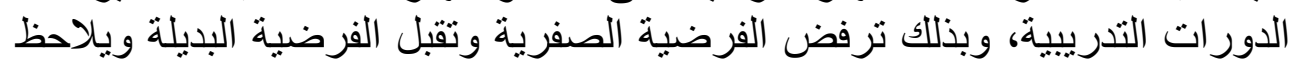

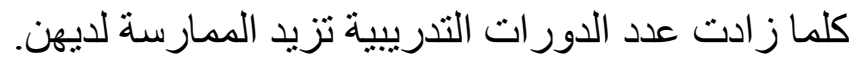

\section{ثانياً: مناقشة نتائج البحث: مناقشة نتائج السؤال الثاني للبحث:}

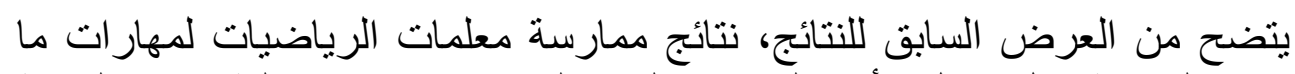

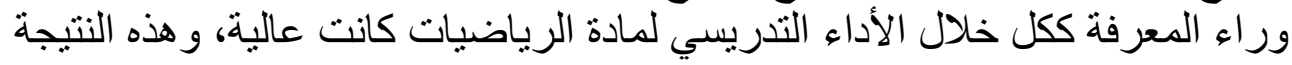

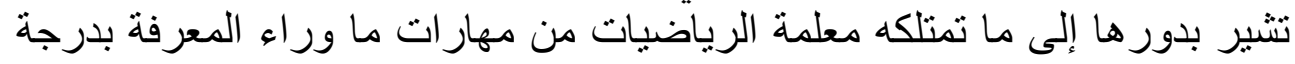

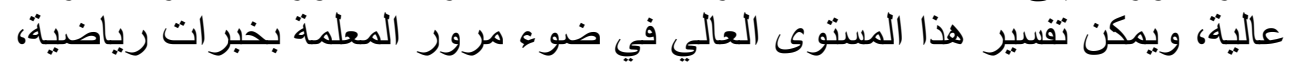

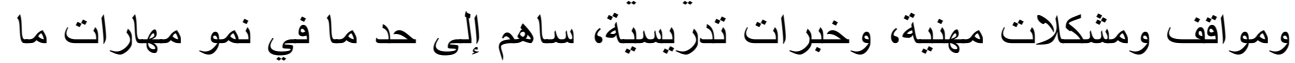

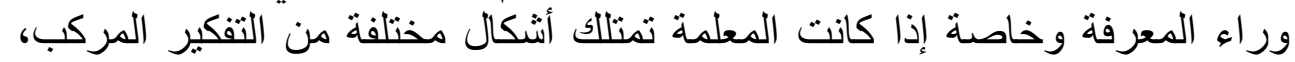

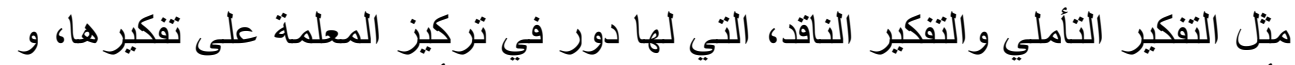

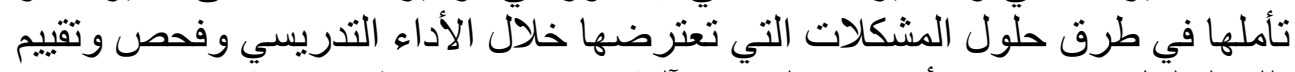

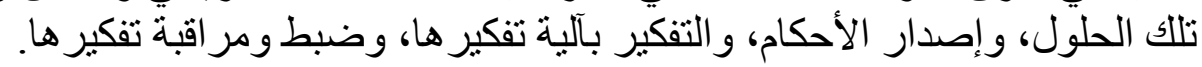

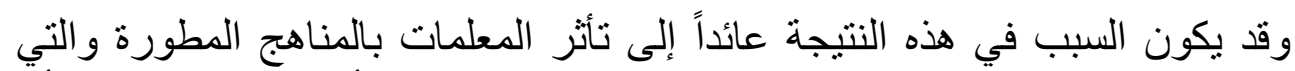

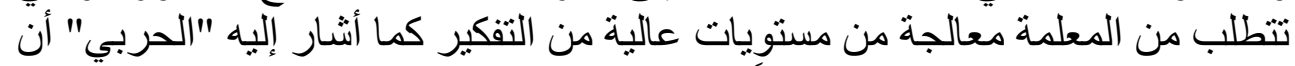

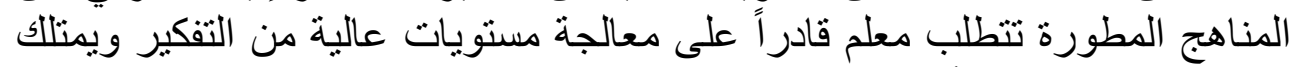

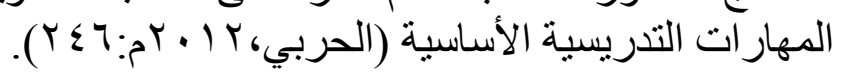

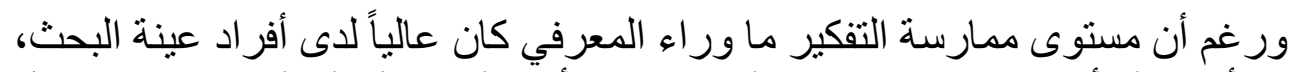

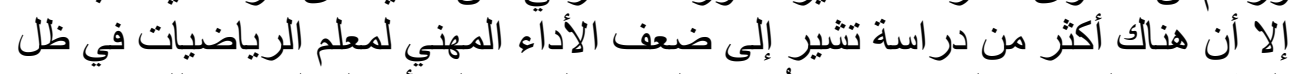

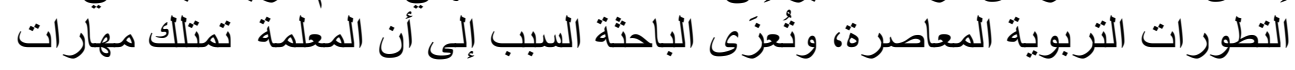

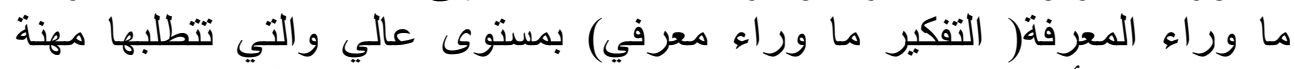

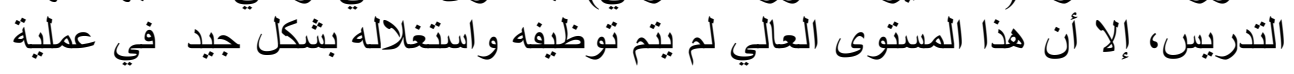


التدريس حتى ينعكس بشكل إيجابي على أداءها ونجاح العملية التعليمية بوجه عام، إلهاء

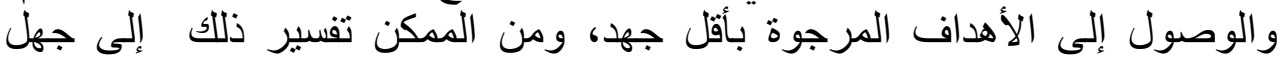

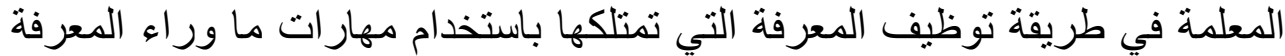

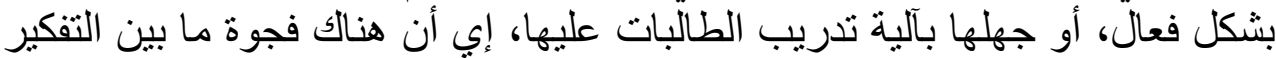
و التطبيق وهذا ما أشنارت إلبه:

در اسة سبريس ( Spruce,2012 ) أن المعلمين لديهم قدرة على وصف الممارسات

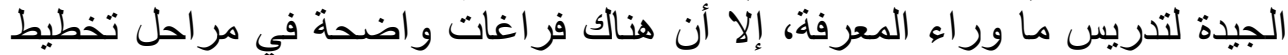

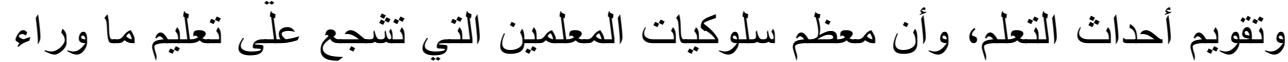

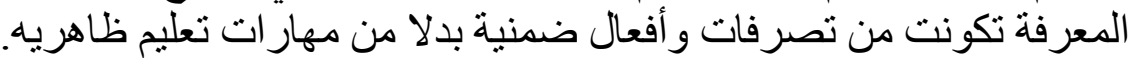

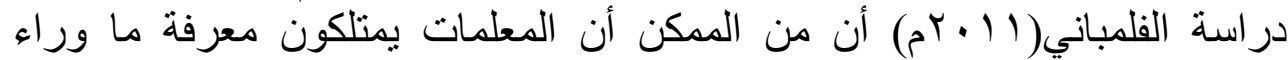
المعرفة في التدريس، ولكن لا بطبقون هذا المعرفة المن من أجل تحسين أدائهم.

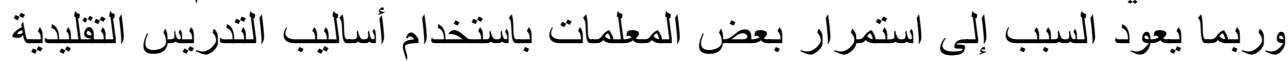

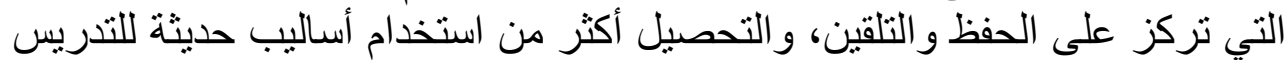

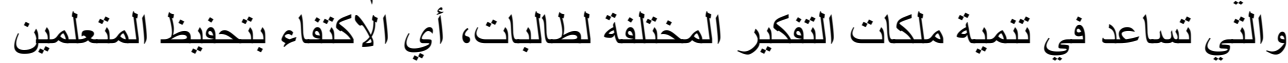

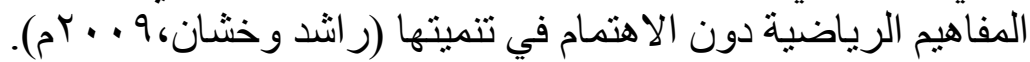

وبما أن مؤشر ات قياس مهار ات ما ور اء المعرفة كان عالياً، فهذا يتطلب من الجهات

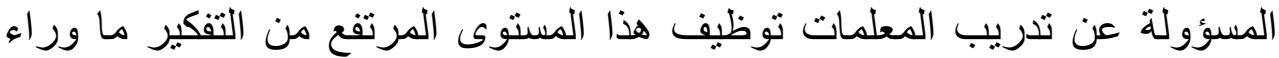

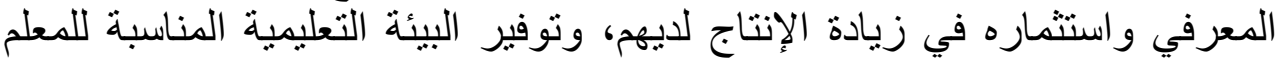

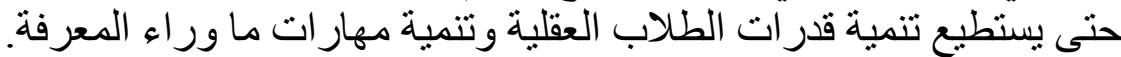

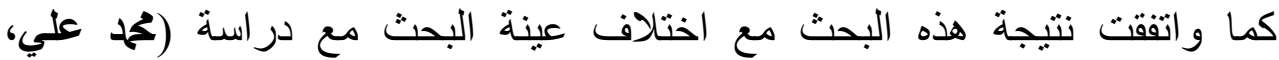

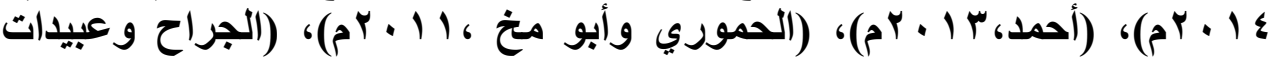

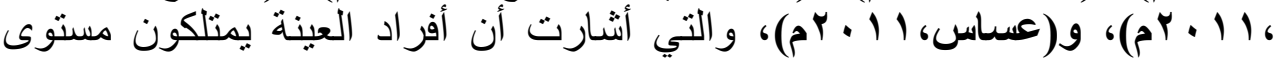

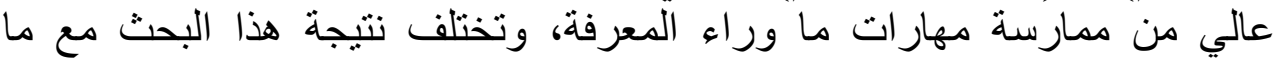

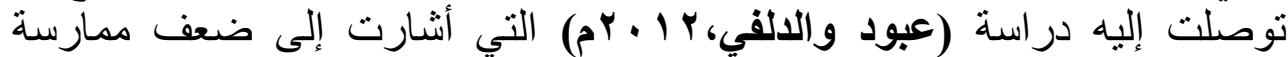

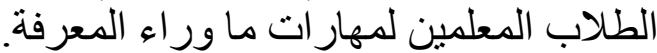

\section{ا. مناقشة نتائج الفرضية الأولى للبحث:}

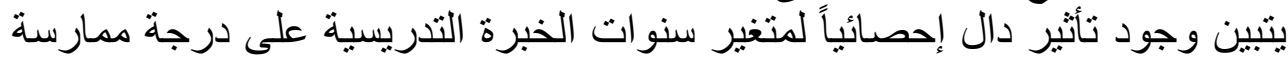

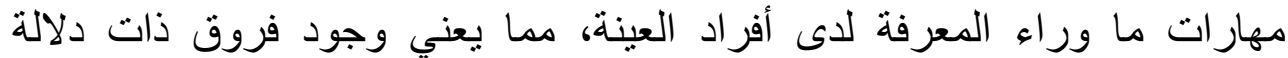

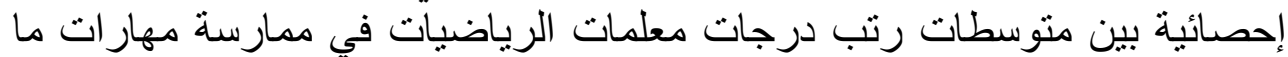
وراء المعرفة في التدريس تعزى إلى سنوات الخبرة التدريسية، وكانت الفريات فئسات 
لصالح الخبرة الأكثر، و على هذا لا تتحقق الفرضية الأولى. ويتضح من ذلك وجود التهاء

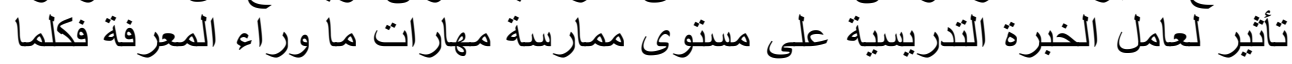

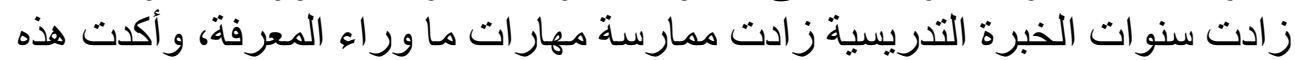

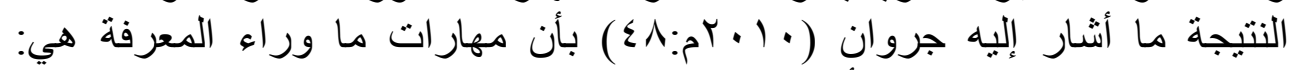

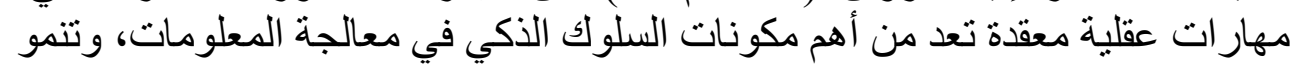

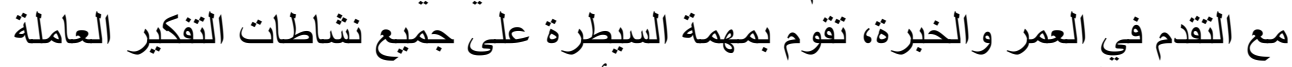

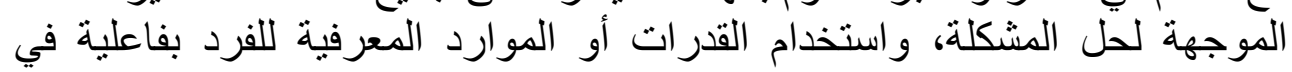
مو اجهة متطلبات مهمة التفكير.

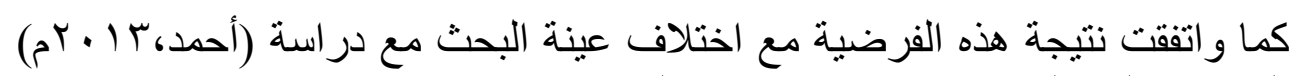

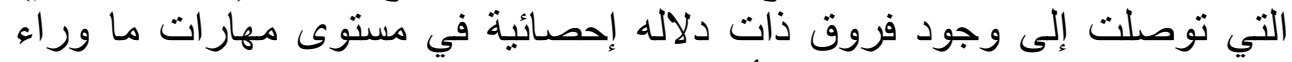

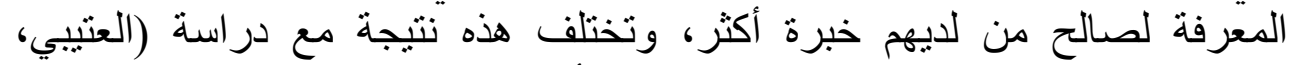

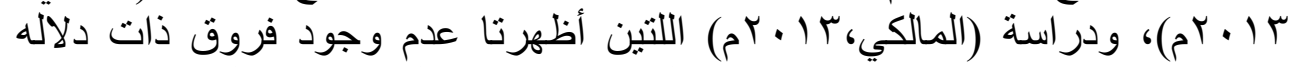

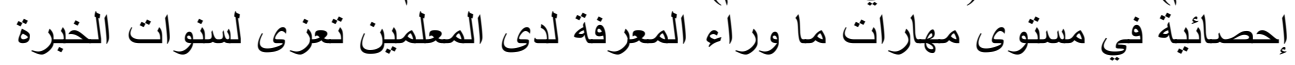

التدربسية.

كما يمكن أن تُعزَى هذه النتيجة من وجهة نظر الباحثة إلى أن التقام بالعمر التهر

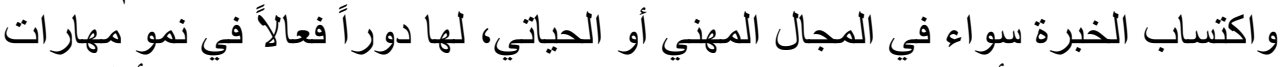

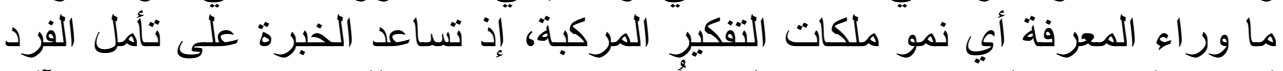

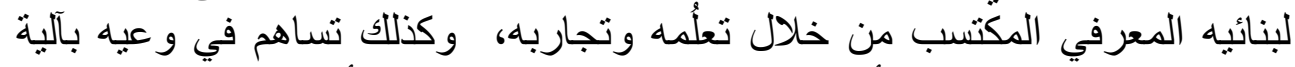

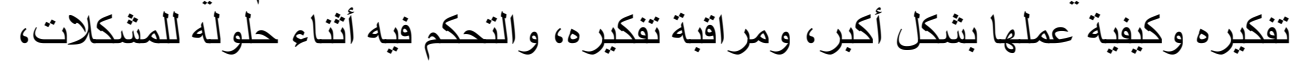

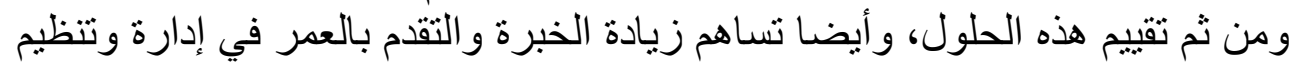

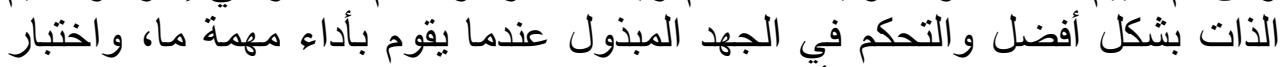

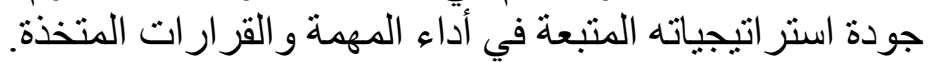

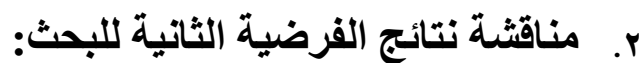

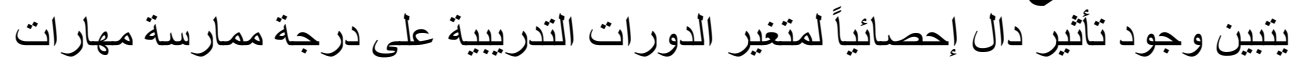

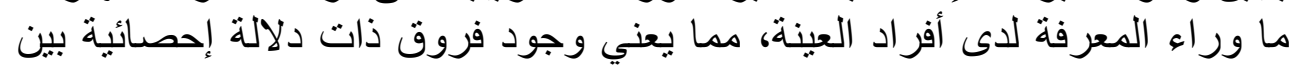

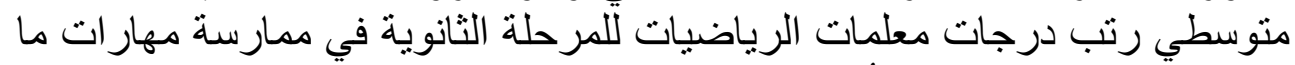

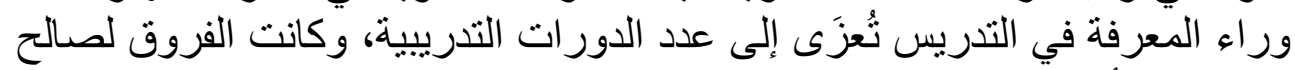

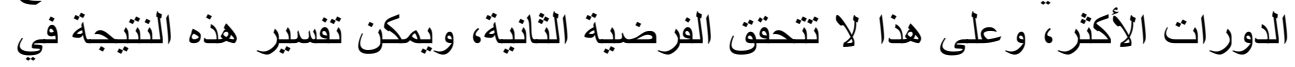

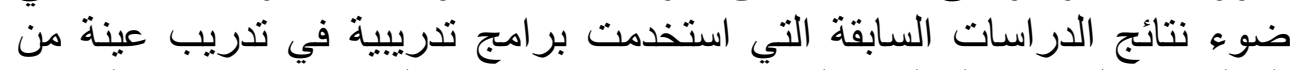

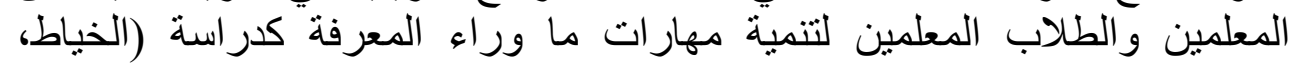




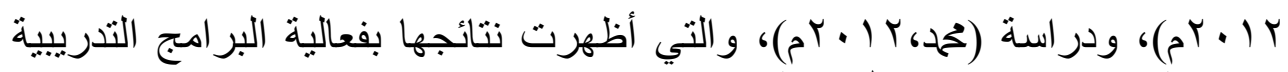

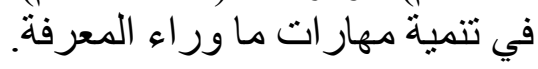

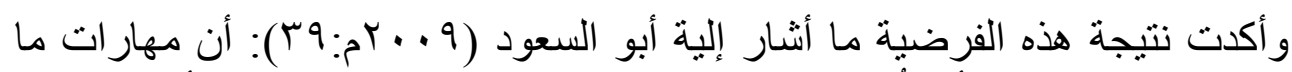

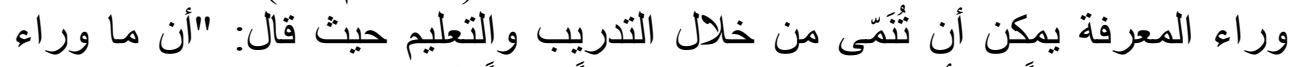

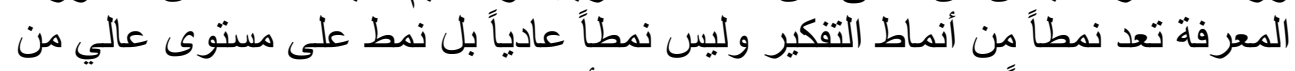

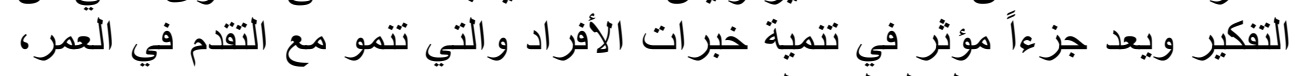

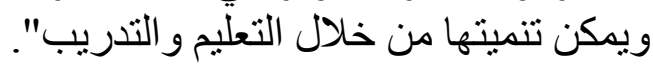

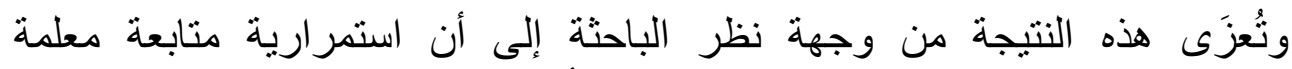

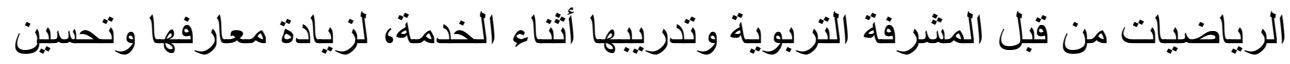

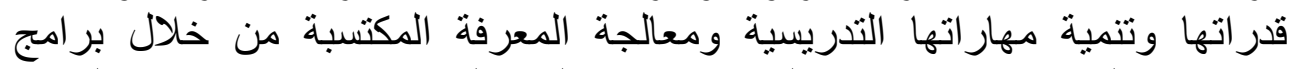

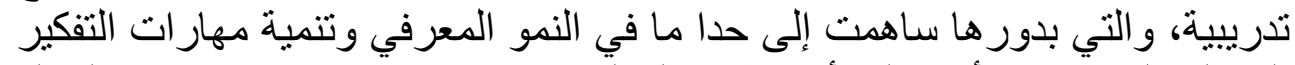

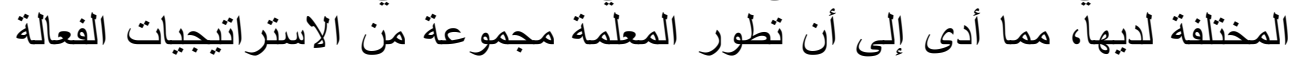

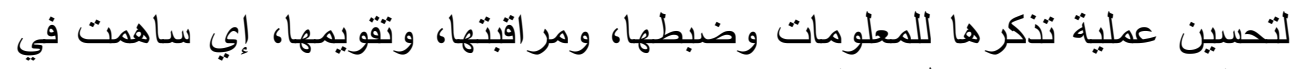

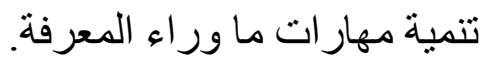

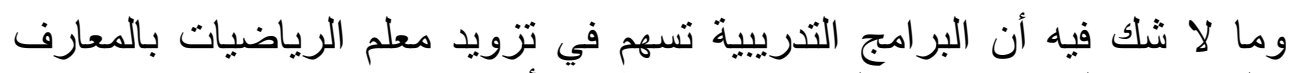

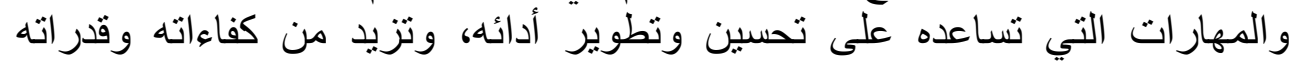

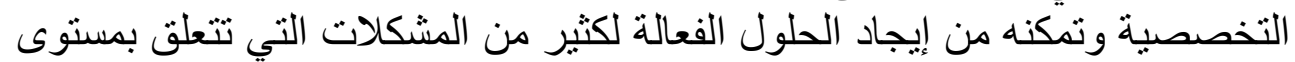

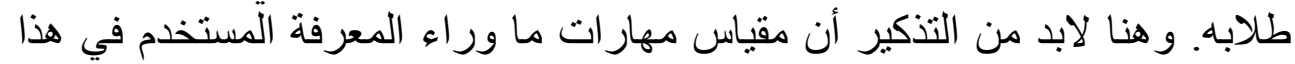

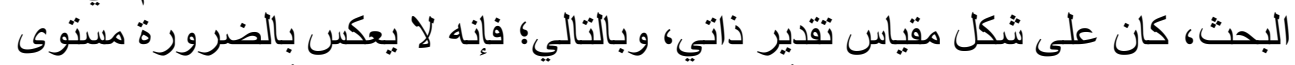

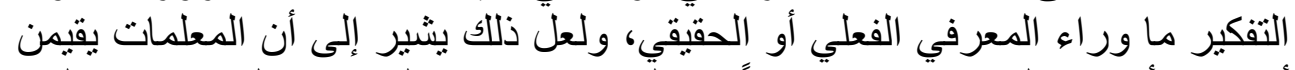

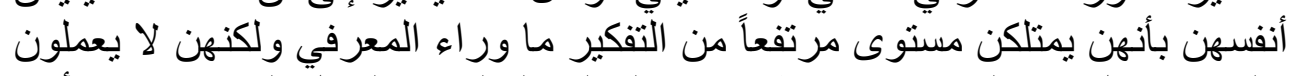

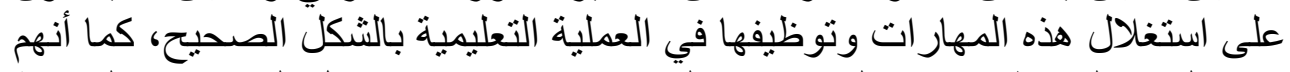

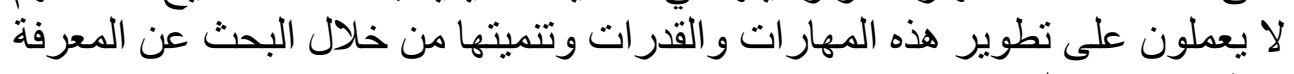
وتطوير بنائهم المعرفي. 


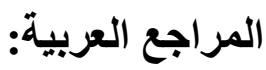

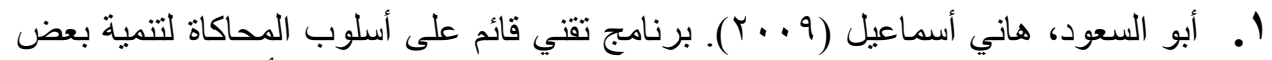

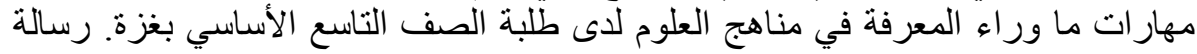
ماجستير غير منشوره. كلية ألتربية .الجامعة الإسلامية بغزة لطية. فلسطين.

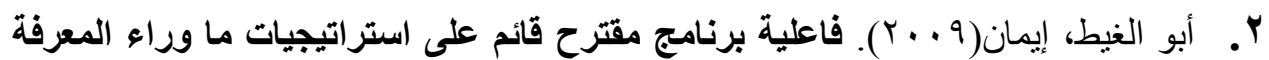

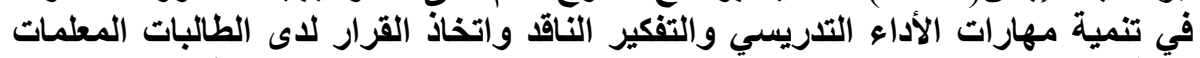

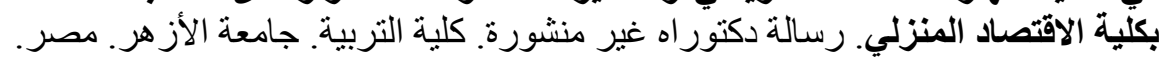

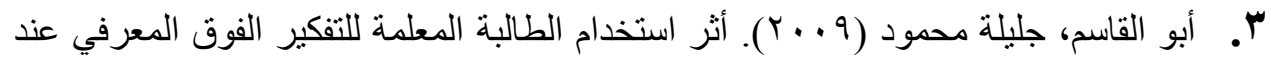

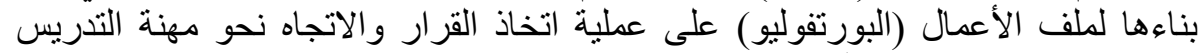

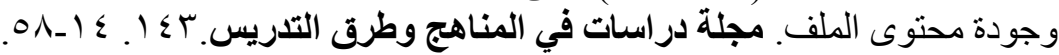

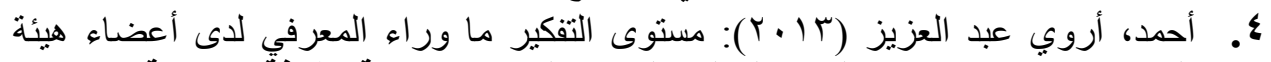

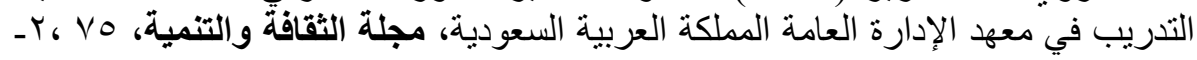
.07

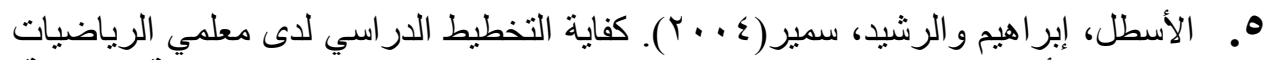

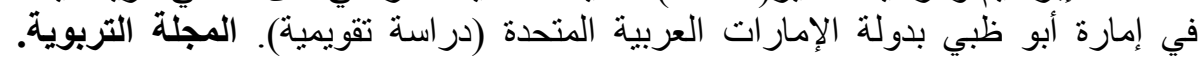

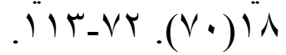

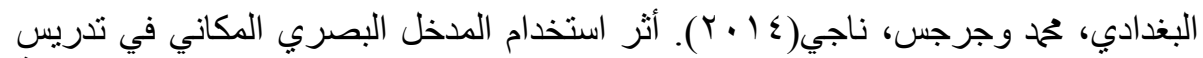

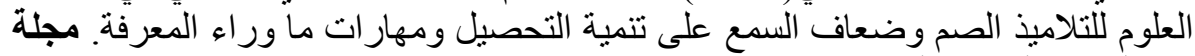

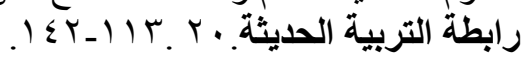

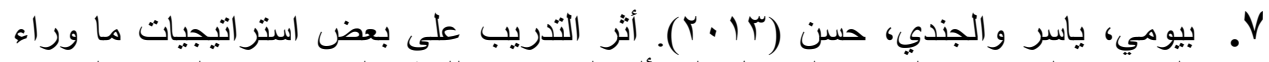

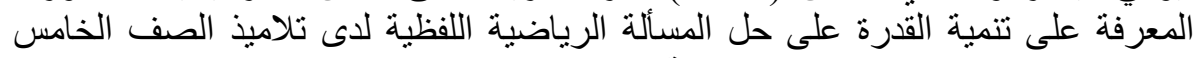

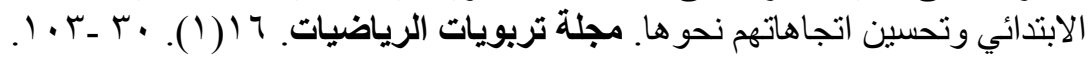

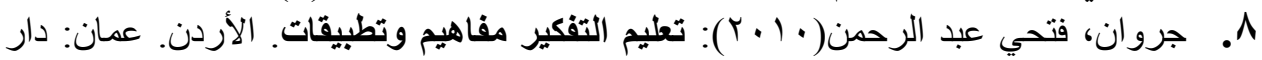
الفكر. طه.

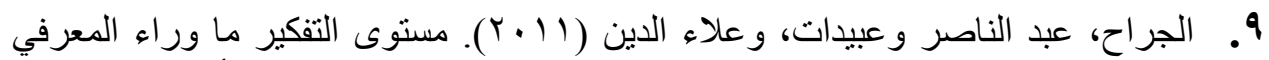

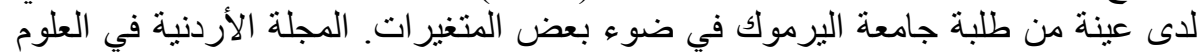

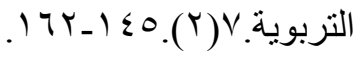

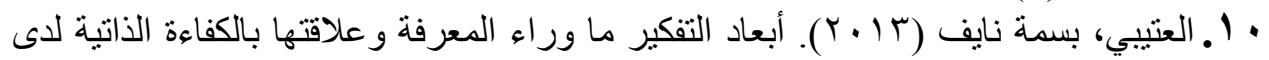

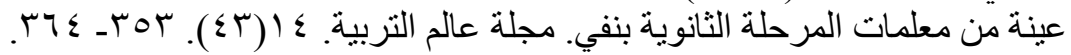

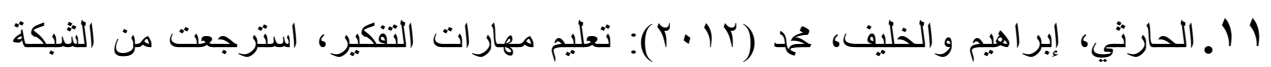

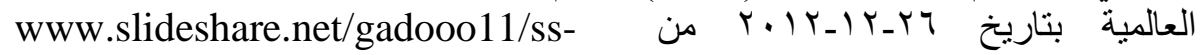
15760968 


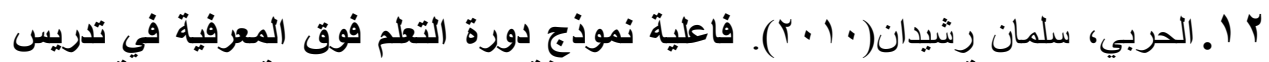

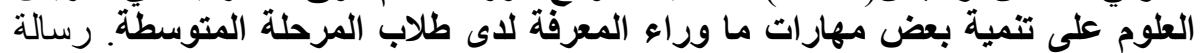

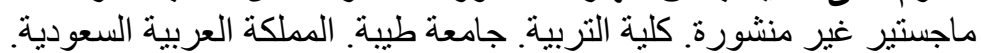

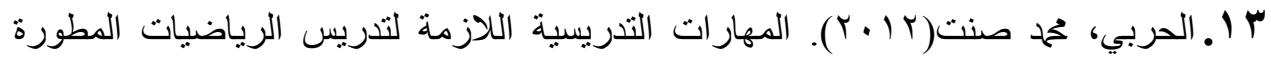

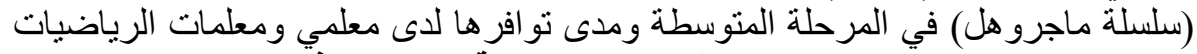

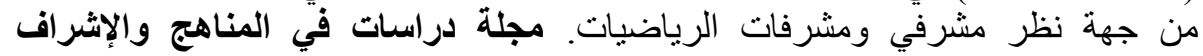

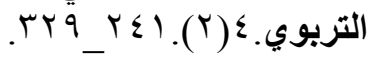

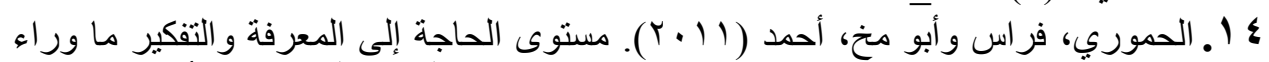

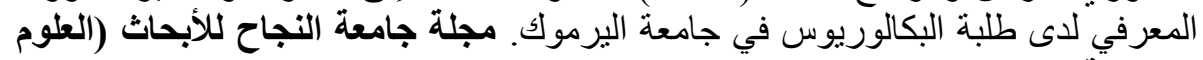

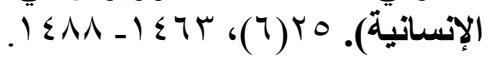

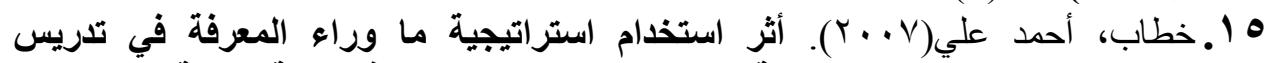

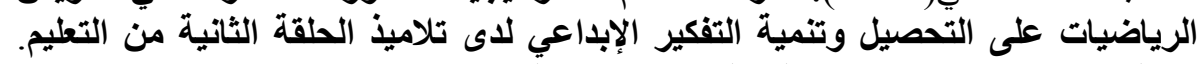

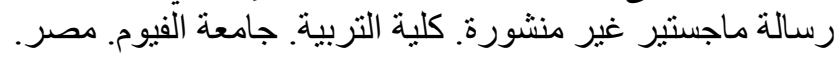

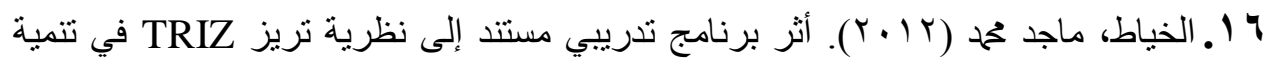

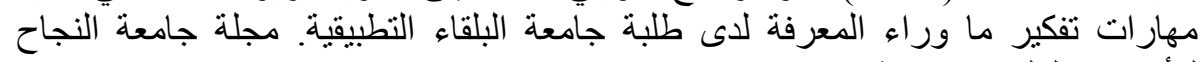

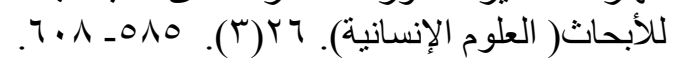

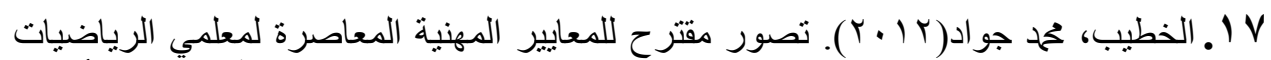

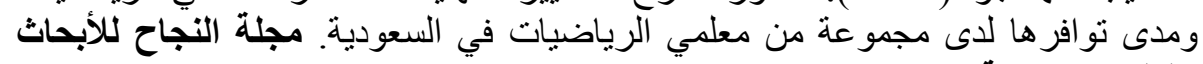

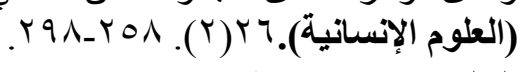

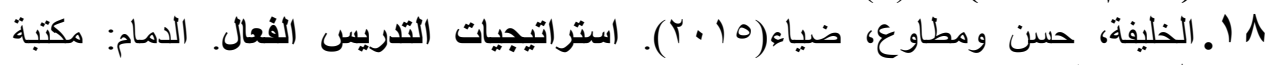

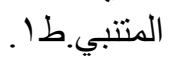

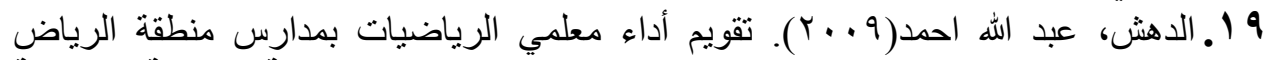

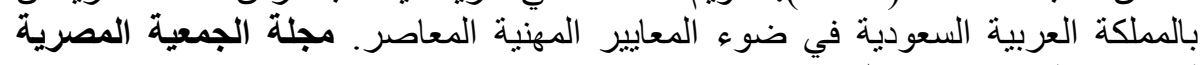

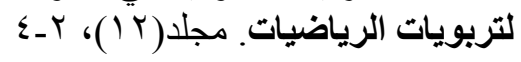

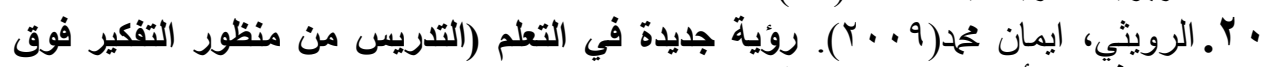

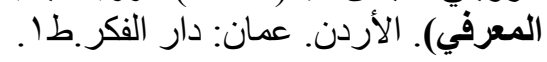

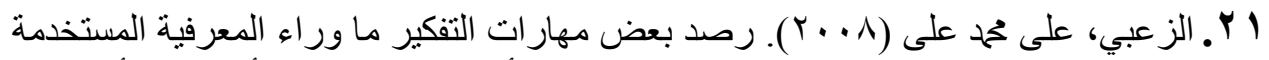

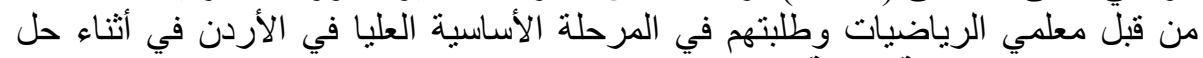

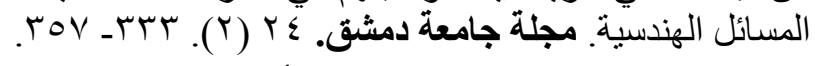

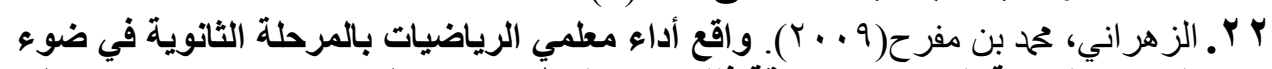

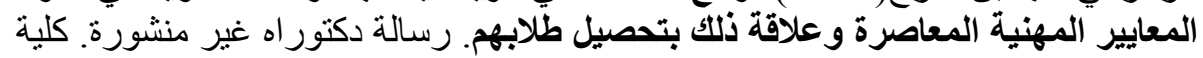

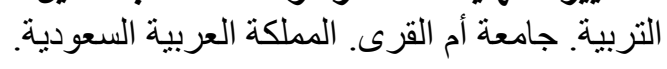

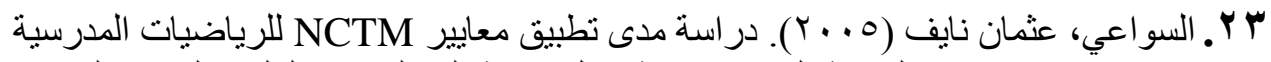

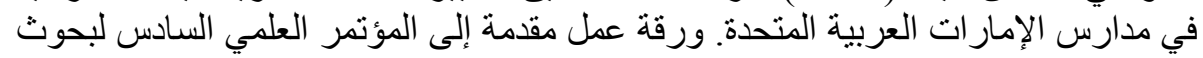

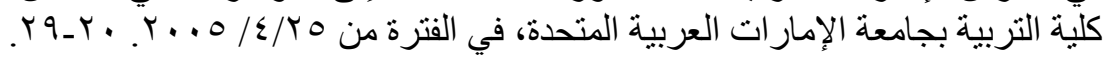




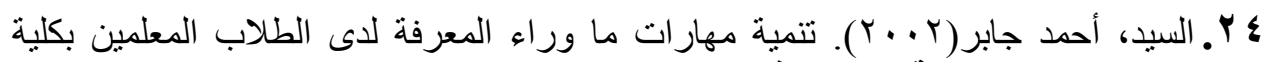

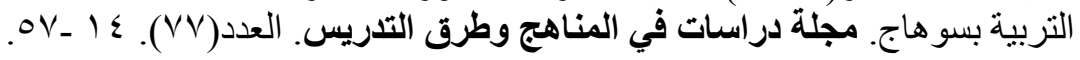

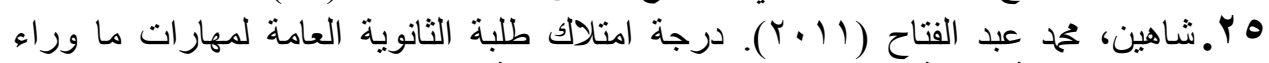

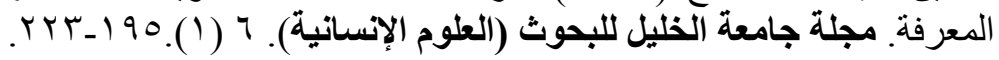

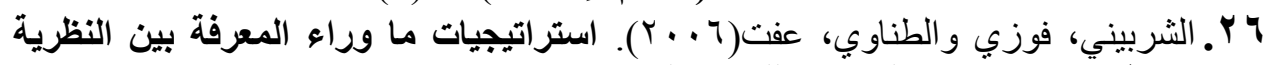

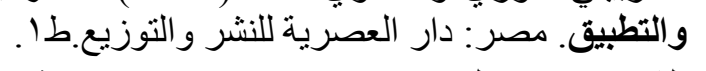
VV

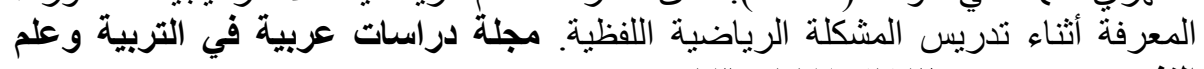

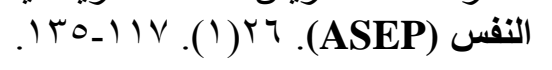

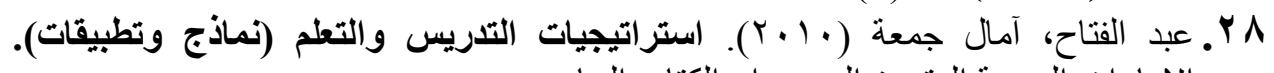

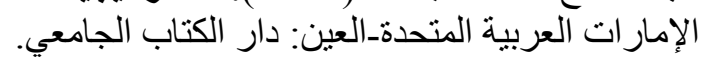

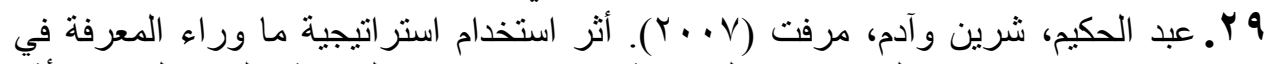

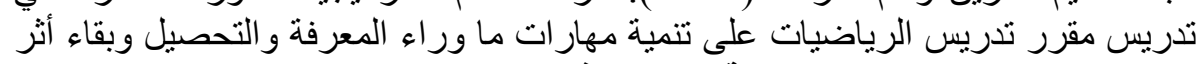

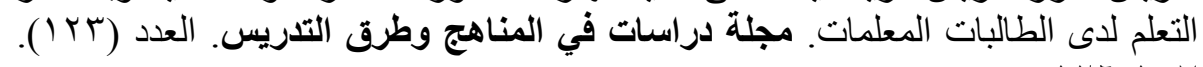
. IT-1.V

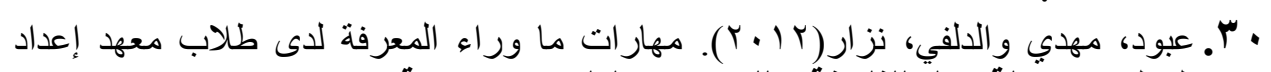

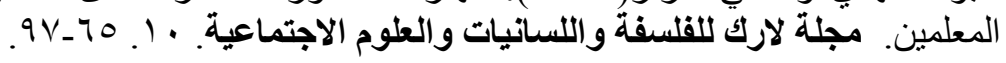

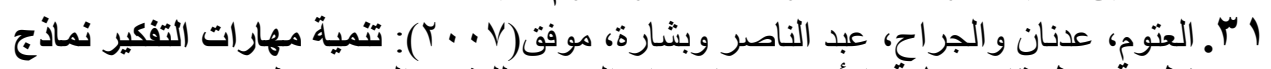

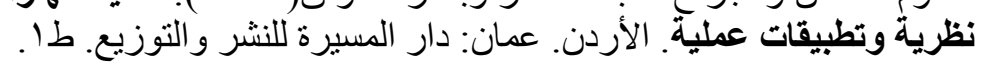

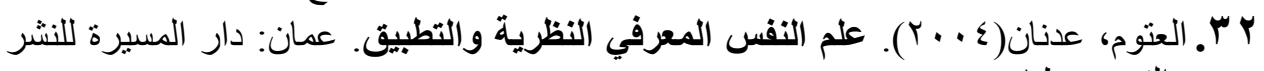
و التوزيع.طان.

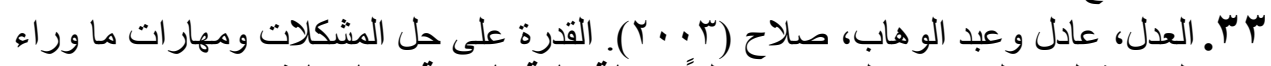

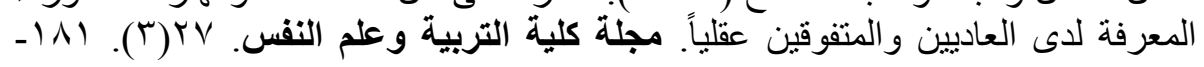
r०9

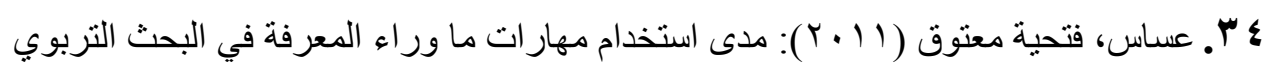

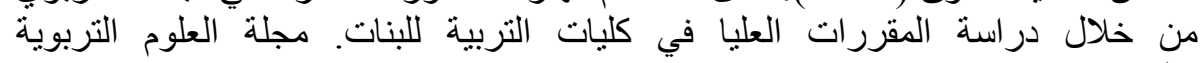

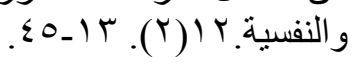

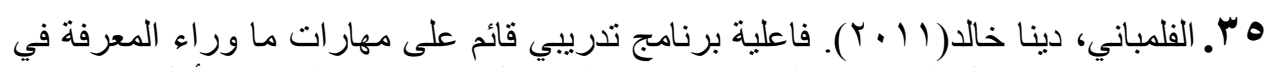

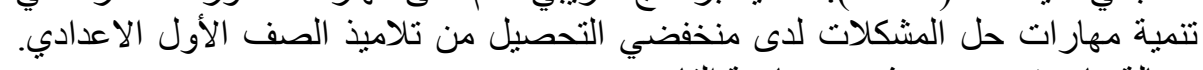

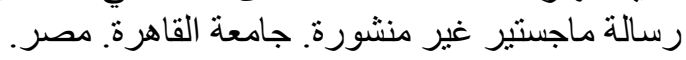

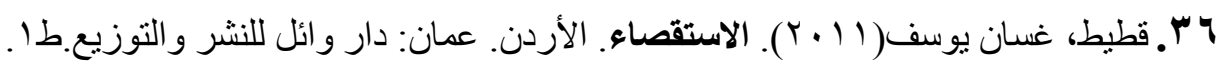

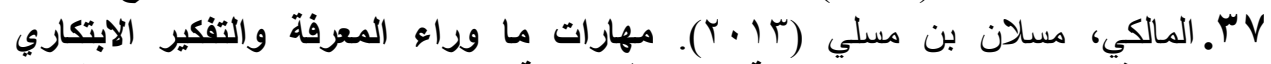

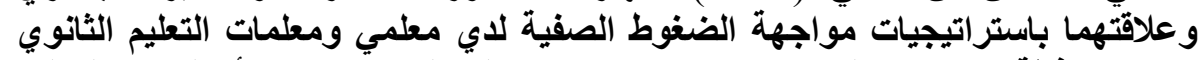

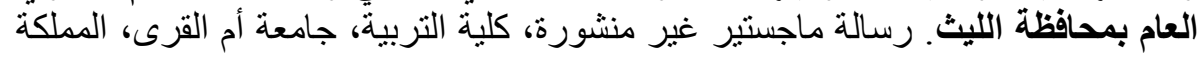
العربية السعودية. 


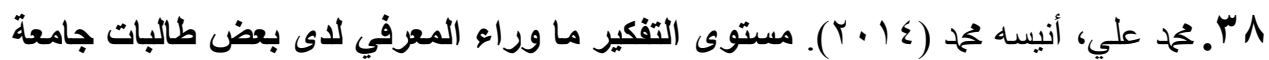

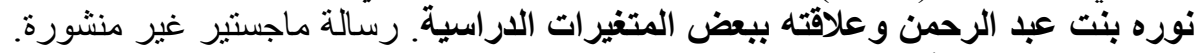
كلية التربية. جامعة أم القرى. المملكة العربية السعو السعودية.

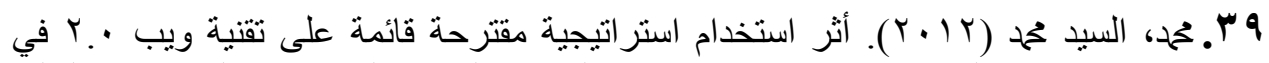

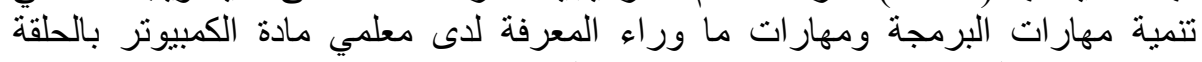

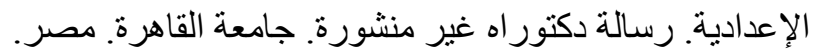

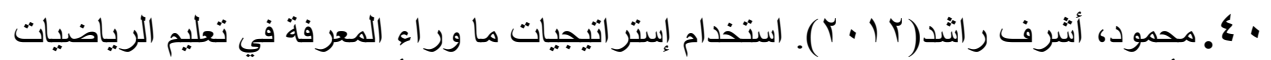

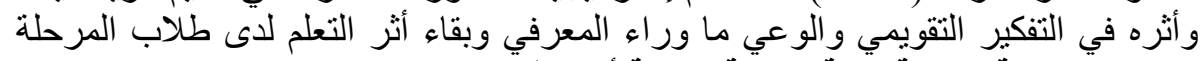

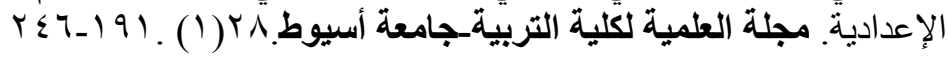

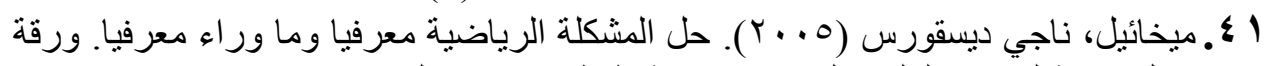

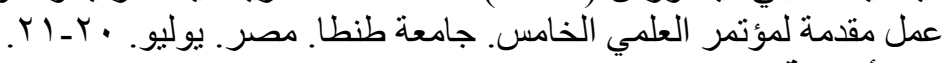

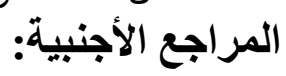

1. Carr, M \& Kourtiz, B(1999). Teacher's Perceptions of Their Students Metacognition Attriutions, and Self Concept .British journal of educational psychology.61(2), 197-206.

2. Cestin, Baris ( 2015 ) . An investigation of teacher candidates metacognitve skills according to their year of study at Canakkale, Educational Research and Reviews, 10 ( 1 ), pp. 10-16.

3. Rahman, fazalur et al(2010). Do metacognitively aware teachers make any difference in students metacognition? .International journal of academic. 2(6).219-223

4. Spruce, Robin S. ( 2012 ). Teacher beliefs, knowledge and practice of metacognition and self-regulated learning, Unpublished Masters Degree, Old Dominion University, USA.

5. Truelove ،Hazel ( 2013 ) . Examining evidence of metacognition by preservice secondary mathematics teachers while solving tasks situated in secondary curriculum 'Unpublished Ph.D. University of Alabama ، USA.

6. Vrieling 'Emmy ( 2012 ) . Consequences of increased self-regulated learning opportunities on student teachers motivation and use of metacognitive skills ‘Australian Journal of Teacher Education ‘37 ( 8 ) 'pp. 102-117. 